\title{
Evaluasi Sistem Manajemen Pada Pelaksanaan Proyek Pembangunan Saranan dan Prasarana Tempat Pelelangan Ikan (TPI) di Tuban Jawa Timur
}

\author{
Sugiyanto $^{1}$, Rendi Untoko \\ Prodi Teknik Sipil Fakultas Teknik Universitas Sunan Bonang Tuban Jawa Timur ${ }^{1,2}$ \\ Email: irsugianto@gmail.com ${ }^{1}$ \\ DOI: http://dx.doi.org/10.31869/rtj.v5i1.2706
}

\begin{abstract}
Abstrak: Pada penelitian ini, evaluasi sistem manajemen pada proyek yang diteliti terdiri dari evaluasi kinerja biaya, evaluasi kinerja jadwal dan evaluasi penerapan mutu pada pelaksanaan proyek. Evaluasi kinerja biaya dan jadwal proyek menggunakan metode konsep nilai hasil (earned value) dan evaluasi penerapan mutu pada pelaksanaan proyek berdasarkan penilaian fisik konstruksi terhadap spesifikasi teknis yang dipersyaratkan. Penggunaan metode nilai hasil untuk mengetahui kinerja biaya dan jadwal proyek dilakukan dengan analisa variabel-variabel BCWS (Budgeted Cost for Work Schedule), ACWP (Actual Cost for Work Performed) dan BCWP (Budgeted Cost for Work Performed), kemudian digambarkan pada kurva $\mathrm{S}$ dengan tampilan informasi sumbu $\mathrm{X}$ menunjukkan durasi proyek dan sumbu Y menyatakan biaya proyek. Kurva S sangat bermanfaat untuk dipakai karena dapat dengan jelas menunjukkan kemajuan proyek dalam bentuk yang mudah dipahami, apakah terjadi pembengkakan atau penghematan anggaran proyek dan apakah terjadi kelambatan atau percepatan dalam jadwal proyek. Berdasarkan evaluasi kinerja biaya proyek, dapat diketahui terjadi pembengkakan biaya aktual proyek terhadap anggaran sebesar Rp. 12.070.959 atau pemborosan biaya sebesar 2.5\% dari total anggaran biaya proyek. Kondisi terjadinya pemborosan anggaran dinamakan cost overrun, hal ini mengindikasikan bahwa pengendalain biaya dalam pelaksanaan proyek yang diteliti masih belum optimal. Berdasarkan atas evaluasi kinerja jadwal proyek, dapat diketahui ada beberapa minggu yang mengalami keterlambatan dan adapula beberapa minggu yang mengalami percepatan. Namun begitu pada masa mendekati batas akhir jadwal proyek, pelaksanaan proyek dapat dicapai tepat jadwal sesuai dengan yang direncanakan. Kondisi tercapainya jadwal pelaksanaan proyek sesuai dengan jadwal yang direncanakan (tepat jadwal) disebut on schedule, hal ini mengindikasikan bahwa dalam pelaksanaan jadwal proyek yang diteliti dapat dikendalikan secara optimal dan tepat sasaran. Adapun untuk evaluasi penerapan mutu, didapatkan bahwa berdasarkan atas penilain fisik konstruksi terhadap spesifikasi teknis yang dipersyaratkan memenuhi persyaratan mutu (persyaratan mutu terpenuhi).
\end{abstract}

Kata kunci: kinerja, nilai hasil, pemborosan, tepat jadwal dan spesifikasi.

Abstract: In this study, the evaluation of the management system in the project under study consisted of cost performance evaluation, schedule performance evaluation and quality implementation evaluation in project implementation. The cost performance evaluation and project schedule used the earned value concept method and the evaluation of the application of quality in project implementation was based on a physical assessment of the construction against the required technical specifications. The use of the yield value method to determine the cost performance and project schedule is carried out by analyzing the variables of BCWS (Budgeted Cost for Work Schedule), ACWP (Actual Cost for Work Performed) and BCWP (Budgeted Cost for Work Performed), then depicted on the $\mathrm{S}$ curve with The $\mathrm{X}$-axis information display shows the project duration and the $\mathrm{Y}$ axis represents the project cost. The $\mathrm{S}$ curve is very useful to use because it can clearly show the progress of the project in an easy-to-understand form, whether there has been an increase or decrease in the project budget and whether there has been a delay or acceleration in the project schedule. Based on the evaluation of the project cost performance, it can be seen that the actual cost of the project against the budget of Rp. 12,070,959 or a waste of $2.5 \%$ of the total project cost budget. The condition where budget wastage occurs is called the cost overrun, this indicates that the cost control in implementing the project under study is still not optimal. Based on the evaluation of the project schedule performance, it can be seen that there are several weeks that experience delays and there are also several weeks that experience acceleration. However, at the time approaching the deadline for the project schedule, project implementation can be achieved on schedule as planned. The condition for 
achieving the project implementation schedule according to the planned schedule (on schedule) is called on schedule, this indicates that the implementation of the project schedule under study can be controlled optimally and on target. As for the evaluation of the application of quality, it was found that based on the physical assessment of the construction against the required technical specifications to meet the quality requirements (quality requirements are met).

Keywords: performance, yield value, waste, on schedule and specifications

\section{PENDAHULUAN}

Seiring dengan berkembangnya negara dan kemajuan teknologi, perbaikan atau pembangunan infrastuktur sangatlah penting. Hal ini dilakukan dalam rangka meningkatkan taraf hidup rakyatnya dalam menjalankan kegiatan perekonomian. Banyak kemajuan yang harus diciptakan, adanya ketertinggalan diusahakan harus dikejar dengan pembangunan di segala bidang. Pembangunan tersebut berupa pembangunan fisik proyek, pembangunan gedung, jembatan, jalan tol, industri besar atau kecil, jaringan telekomunikasi, jaringan transportasi dan bandara dan lain-lain.

Gray dkk. (2007) menyebutkan bahwa proyek adalah kegiatan-kegiatan yang dapat direncanakan dan dilaksanakan dalam satu bentuk kesatuan dengan mempergunakan sumber-sumber untuk mendapatkan benefit. Kegiatankegiatan tersebut dapat berbentuk investasi baru seperti pembangunan pabrik, pembangunan fasilitas pelayanan publik, pembuatan jalan raya atau kereta api, irigasi, bendungan, pendirian gedung sekolah, survei atau penelitian, perluasan program yang sedang berjalan, dan sebagainya.

Rani (2016) mengatakan bahwa manajemen dalam pelaksanaan proyek konstruksi dilakukan dengan perencanaan dan penjadwalan, yaitu proses yang mencoba meletakkan dasar tujuan dan dasar sasaran termasuk menyiapkan segala sumber daya, yang meliputi money (uang), material (bahan), machine (peralatan), man-power (tenaga manusia), market (pasar), method (metode), information (informasi), space (ruang), dan time (waktu). Pada setiap proyek konstruksi, terdapat sumber daya-sumber daya tersebut yang akan diproses, pada saat proses inilah diperlukan manajemen agar proses ini berjalan efektif dan efisien, serta diperoleh hasil yang memuaskan. Dengan demikian, tujuan dan sasaran proyek konstruksi akan semakin mudah untuk dicapai. Tujuan dalam pelaksanaan konstruksi adalah untuk menyelesaikan pekerjaan dan mendapat keuntungan dari total biaya yang dikeluarkan. Adapun sasaran dalam pelaksanaan proyek konstruksi adalah untuk menata pekerjaan konstruksi agar pekerjaan tersebut berlangsung efektif dan efisien.

Semakin maju peradaban manusia, semakin besar dan semakin kompleks proyek yang dikerjakan dengan melibatkan penggunaan bahan-bahan (material), tenaga kerja, dan teknologi yang makin canggih. Proyek pada umumnya memiliki batas waktu (deadline), anggaran, serta spesifikasi yang telah ditentukan; artinya proyek harus diselesaikan pada waktu yang telah ditentukan dengan anggaran yang telah sediakan serta mutu sesuai dengan harapan. Setiap proyek perlu adanya evaluasi agar mengetahui sejauh mana pelaksanaan dan tingkat keberhasilan proyek itu sendiri. Berkaitan dengan masalah proyek ini, maka keberhasilan pelaksanaan sebuah proyek tepat pada waktunya, sesuai anggaran dan mutu bisa diterima merupakan tujuan yang penting baik bagi pemilik proyek maupun kontraktor.

Keberhasilan ataupun kegagalan dari pelaksanaan sering kali disebabkan kurang terencananya kegiatan proyek serta pengendalian yang kurang efektif, sehingga kegiatan proyek tidak efisien. Hal ini akan mengakibatkan keterlambatan, menurunnya kualitas pekerjaan, dan membengkaknya biaya pelaksanaan. Keterlambatan penyelesaian proyek sendiri adalah kondisi yang sangat tidak dikehendaki, karena hal ini dapat merugikan kedua belah pihak baik dari segi waktu maupun biaya. Dalam 
kaitannya dengan waktu dan biaya produksi, perusahaan harus bisa seefisien mungkin dalam penggunaan waktu di setiap kegiatan atau aktivitas, sehingga biaya dapat diminimalkan dari rencana semula.

PT. Srikandi Dua Putri sebagai unsur pelaksana pengadaan pekerjaan konstruksi bertugas menyelenggarakan pembangunan sarana dan prasarana tempat pelelangan ikan (TPI) di Tuban Kabupaten Tuban Provinsi Jawa Timur. Aktivitas pembangunan tempat pelelangan ikan (TPI) meliputi beberapa aktivitas besar, yaitu pekerjaan persiapan, pekerjaan pengurugan, pemasangan beton, dan pembangunan gedung, serta penyediaan fasilitas kelengkapannya. Proyek pembangunan ini dilakukan untuk memberikan tempat yang lebih representatif/layak bagi para nelayan untuk memudahkan aktifitas jual beli ikan hasil tangkapan serta meningkatkan kenyamanan dan pelayanan bagi pembeli ikan di Kota Tuban. Disamping itu, pembangunan proyek tersebut dimaksudkan untuk lebih mengkonsentrasikan dan meningkatkan pelayanan bagi para pelaku UKM (usaha kecil menengah) melakukan aktifas penjualan berbagai produk hasil olahan ikan ciri khas Tuban.

Dalam suatu kondisi pemilik proyek seringkali mengalami beberapa masalah, baik karena faktor eksternal maupun internal, sehingga proyek memiliki perkembangan yang buruk sehingga implementasi proyek tidak seperti yang direncanakan, atau dapat dikatakan kemajuan proyek berjalan lebih lambat, anggaran membengkak, dan mutu tidak sesuai spesifikasi. Hal ini juga berlaku terhadap proyek pembangunan sarana dan prasaranan tempat pelelangan ikan (TPI) di Tuban. Bagaimana penerapan sistem manajemen oleh kontraktor dalam pelaksanaan pembangunan proyek tersebut, ditinjau dari biaya, jadwal, dan mutu bisa dicapai. Oleh karena itu diperlukan adanya penelitian tentang evaluasi sistem manajemen pada pelaksanaan proyek pembangunan sarana dan prasarana tempat pelelangan ikan (TPI) di Tuban.

\section{METODE PENELITIAN}

Secara lebih detail data proyek yang dikerjakan termasuk dalam lingkup Dinas Perikanan Dan Peternakan Kabupaten Tuban adalah sebagai berikut:

\begin{tabular}{|c|c|}
\hline 1. Nama & Pembangunan Sarana dan Prasarana Tempat \\
\hline Kegiatan & Pelelangan Ikan (TPI) Tuban \\
\hline Proyek : & \\
\hline 2. Pemilik & Dinas Perikanan dan Peternakan Kabupaten \\
\hline Proyek : & Tuban \\
\hline & APBD-Tahun Anggaran 2019 \\
\hline Sumber & \\
\hline Dana : & \\
\hline 4. Kontraktor & PT. Srikandi Dua Putri \\
\hline 5. Nilai & Rp. 4.797.076.041,00 (\#Empat Milyar Tujuh \\
\hline Kontrak & Ratus Sembilan Puluh Tujuh Juta Tujuh \\
\hline Fisik : & $\begin{array}{l}\text { Puluh Enam Ribu Empat Puluh Satu } \\
\text { Rupiah\#). Tidak termasuk PPN } 10 \%\end{array}$ \\
\hline 6. Nomor & 602.1/21.80.08a.F/PPK.APBD/414.110/2020 \\
\hline Kontrak : & \\
\hline $\begin{array}{l}\text { 7. Jangka } \\
\text { Waktu } \quad\end{array}$ & 150 Hari Kalender \\
\hline
\end{tabular}

Untuk memudahkan dalam analisis dan pengolahan data, maka dalam pelaksanaan penelitian ini proses pengamatan dan pengambilan data dikelompokkan dengan pembagian dalam periode mingguan (data per minggu). Jadwal proyek dimulai dari tanggal 12 Juli 2020 sampai dengan batas akhir penyelesaian proyek tanggal 8 Desember 2020, maka didapatkan data hasil pengamatan sebanyak 22 minggu terdiri dari periode:

1. Minggu ke-1 = 12 Juli s/d 14 Juli 2020

2. Minggu ke- $2=15$ Juli s/d 21 Juli 2020

3. Minggu ke- $3=22$ Juli s/d 28 Juli 2020

4. Minggu ke- $4=29$ Juli s/d 4 Agustus 2020

5. Minggu ke-5 $=5$ Agustus s/d 11 Agustus 2020

6. Minggu ke- $6=12$ Agustus s/d 18 Agustus 2020

7. Minggu ke-7 $=19$ Agustus s/d 25 Agustus 2020

8. Minggu ke- $8=26$ Agustus s/d 1 September 2020

9. Minggu ke- $9=2$ September $\mathrm{s} / \mathrm{d} 8$ September 2020

10. Minggu ke-10 $=9$ September s/d 15 September 2020

11. Minggu ke-11 =16 September s/d 22 September 2020

12. Minggu ke-12 $=23$ September $\mathrm{s} / \mathrm{d} 29$ September 2020

13. Minggu ke-13 $=30$ September $s / d 6$ Oktober 2020

14. Minggu ke-14 $=7$ Oktober s/d 13 Oktober 2020

15. Minggu ke-15 $=14$ Oktober s/d 20 Oktober 2020

16. Minggu ke-16 $=21$ Oktober s/d 27 Oktober 2020

17. Minggu ke-17 $=28$ Oktober s/d 3 Nopember 2020

18. Minggu ke- $18=4$ Nopember $s / d 10$ Nopember 2020

19. Minggu ke-19=11 Nopember s/d 17 Nopember 2020

20. Minggu ke-20 $=18$ Nopember s/d 24 Nopember 2020 (Durasi 7 hari)

21. Minggu ke-21 $=25$ Nopember s/d 1 Desember 2020 (Durasi 7 hari)

22. Minggu ke-22 $=2$ Desember s/d 8 Desember 2020

Total jadwal pelaksanaan proyek $=22$ minggu (Total durasi 150 hari) 
Metode pengumpulan data yang gigunakan pada penelitian ini adalah terdiri dari 2 (dua) metode, yaitu meliputi:

1. Observasi (pengamatan langsung)

Pengamatan ini dilakukan secara mandiri atau dengan melibatkan bantuan pekerja untuk mendapatkan data yang akurat dan sesuai dengan kebutuhan. Adapun data yang dimaksud adalah terdiri dari:

a. Biaya pengeluaran proyek

Biaya pengeluaran proyek meliputi biaya aktual, terdiri dari pencatatan pengeluaran biaya harian, kemudian direkap menjadi periode mingguan (data pengamatan per minggu).

b. Waktu pelaksanaan proyek

Waktu pelaksanaan proyek meliputi waktu pengerjaan yang dibutuhkan dalam pelaksanaan proyek secara aktual, baik tiap tahapan proyek maupun waktu pelaksanaan proyek secara keseluruhan.

c. Mutu pelaksanaan proyek

Mutu pelaksanaan proyek meliputi mutu yang diaplikasikan dalam proyek, terdiri dari mutu aktual yang diaplikasikan pada proyek.

2. Pengamatan tidak langsung

Pengamatan ini berasal dari sumber/pihak lain yang terkait dalam pelaksanaan proyek terdiri sebagai berikut ini:

a. Rancangan atau desain proyek

Rancangan atau disain proyek meliputi tes tanah, analisa struktur, gambar kerja, dan lainnya.

b. Rancangan anggaran belanja proyek (RAB)

Rancangan anggaran belanja proyek terdiri dari daftar rekapitulasi biaya, volume dan harga satuan pekerjaan, harga satuan upah, harga satuan bahan, analisa harga satuan pekerjaan, dan lainnya. RAB ini terdiri dari perincian tiap aktivitas pekerjaan dan kemudian direkap menjadi anggaran biaya per periode data pengamatan mingguan.

c. Rencana Waktu Proyek (Time Schedule) Rencana waktu proyek terdiri dari schedule harian, schedule mingguan, bulanan dan waktu tertentu.

d. Rencana kerja dan syarat pelaksanaan proyek (RKS)

Rencana kerja dan syarat pelaksanaan proyek terdiri dari persyaratan administrasi dan umum, bahan, spesifikasi, pekerjaan, dan lainnya.

Pada penelitian ini pengukuran variabel menggunakan metode konsep nilai hasil (earned value) terdiri dari pengukuran kinerja biaya dan jadwal. Pengukuran mutu fisik konstruksi terpisah dengan pengukuran kinerja biaya dan jadwal. Dengan demikian, pengukuran variabel terdiri dari:

1. Penghitungan variabel-variabel, indikatorindikator, serta indek-indek yang berkaitan dengan konsep nilai hasil (earned value), untuk menentukan kinerja biaya dan kinerja jadwal dalam pelaksanaan proyek.

2. Pengukuran mutu fisik konstruksi dilakukan oleh pengawas teknik melalui penilaian kondisi aktual pelaksanaan proyek dengan gambar rencana dan spesifikasi teknis dalam rencana kerja dan syarat-syarat pekerjaan (RKS).

Berdasarkan atas ketentuan pengukuran variabel seperti dijelaskan di atas, maka dalam penelitian ini, pengukuran variabel adalah meliputi sebagai berikut ini:

1. Variabel $A C W P$

Actual Cost for Work performed (ACWP) adalah jumlah biaya aktual dari pekerjaan yang telah dilaksanakan. ACWP didapat dari data akutansi pada tanggal pelaporan, yaitu catatan segala pengeluaran biaya aktual dari paket kerja. ACWP merupakan biaya aktual yang diperlukan untuk membiayai proyek dari awal hingga selesai, disusun dalam pengeluaran aktual mingguan (per minggu) sesuai dengan kebutuhan yang diperlukan dalam analisis dan pengolahan data pada penelitian ini.

2. Variabel $B C W P$

Budgeted Cost for Work Performed $(B C W P)$ adalah nilai yang diterima dari penyelesaian pekerjaan selama periode waktu tertentu. $B C W P$ inilah yang disebut earned value, dihitung berdasarkan akumulasi dari pekerjaan-pekerjaan yang telah diselesaikan. Variabel $B C W P$ dapat diperoleh dengan perhitungan rumus sebagai berikut:

$B C W P=$ Bobot Penyelesaian Pekerjaan $(\%) \mathrm{x}$

3. Variabel $B C W S$

Budgeted Cost for Work Scheduled (BCWS) adalah biaya yang dialokasikan berdasarkan rencana kerja yang disusun terhadap waktu. 
$B C W S$ dihitung dari penjumlahan biaya yang direncanakan untuk pekerjaan dalam periode waktu tertentu. Variabel $B C W S$ dalam aplikasi dalam proyek adalah biaya yang dianggarkan untuk menyelesaikan kegiatan proyek, disusun dalam rekap anggaran mingguan (per minggu) sesuai dengan kebutuhan yang diperlukan dalam analisis dan pengolahan data pada penelitian ini.

4. Indikator $C V$

Cost Variance $(\mathrm{CV})$ adalah perbedaan nilai yang diperoleh setelah menyelesaikan bagian pekerjaan dengan nilai aktual pelaksanaan proyek. Nilai dari indikator $C V$ dapat diperoleh dengan perhitungan rumus seperti di bawah ini:

$$
C V=B C W P-A C W P
$$

5. Indikator $S V$

Schedule variance $(S V)$ adalah perbedaan bagian pekerjaan yang dapat dilaksanakan $(B C W P)$ dengan bagian pekerjaan yang direncanakan $(B C W S)$. Nilai indikator $S V$ dapat diperoleh dengan perhitungan rumus seperti di bawah berikut ini:

$$
S V=B C W P-B C W S
$$

6. Indek $C P I$

Cost Performance Index (CPI) adalah perbandingan antara nilai yang diterima dari penyelesaian pekerjaan dengan biaya aktual yang dikeluarkan untuk menyelesaikan pekerjaan tersebut. Nilai indek $C P I$ dapat diperoleh dari perhitungan rumus sebagai berikut:

$$
C P I=B C W P: A C W P
$$

7. Indek $S P I$

Schedule performance index (SPI) adalah perbandingan antara penyelesaian pekerjaan di lapangan dengan rencana kerja pada periode waktu tertentu. Nilai indek SPI dapat diperoleh dengan perhitungan rumus sebagai berikut ini:

$$
S P I=B C W P: B C W S
$$

8. Evaluasi penerapan standar mutu pada pelaksanaan proyek
Evaluasi penerapan standar mutu pada pelaksanaan proyek adalah dengan evaluasi (membandingkan) penerapan antara perencanaan pekerjaan (work planning) dengan kontrol mutu (quality control) terhadap aplikasi aktual dalam proyek baik dari standar tenaga kerja yang digunakan, volume pekerjaan, kualitas material, dan yang lain sebagainya.

Analisis data yang dalam penelitian ini dengan penerapan aplikasi perangkat lunak (software) komputer terdiri dari:

1. Analisi deskriptif kuantitatif menggunakan software microsoft excel. Analisis ini dilakukan untuk menghitung dan mengolah data kuantitatif terdiri dari data anggaran biaya, durasi pekerjaan, penghitungan indikator kinerja biaya dan jadwal proyek, penghitungan indek kinerja biaya dan jadwal dan rincian biaya pada pelaksanaan proyek pembangunan sarana dan prasarana tempat pelelangan ikan (TPI).

2. Analisi deskriptif kuantitatif menggunakan software microsoft word. Analisis ini dilakukan untuk mendapatkan grafik dari Kurva $\mathrm{S}$ yang menggambarkan progress kemajuan proyek yang sedang diteliti. Bentuk Kurva S terdiri dari pemaduan kemajuan setiap tambahan waktu untuk mendapatkan kemajuan komulatif yang digunakan dalam pemantauan pekerjaan. Ukuran kemajuan dititikberatkan pada progress kerja dan biaya. Sumbu $\mathrm{X}$ menunjukan skala waktu (durasi pelaksanaan proyek), sedangkan pada sumbu Y merupakan skala biaya atau prestasi kerja, yang terdiri dari variabelvariabel $B C W S, A C W P$ dan $B C W P$.

\section{HASIL DAN PEMBAHASAN \\ Evaluasi Kinerja Biaya Proyek}

Berdasarkan atas data dari sumber data (pihak kedua) yang diperoleh pada Rancangan Anggaran Belanja (RAB) pada Proyek Pembangunan Sarana dan Prasarana Tempat Pelelangan Ikan (TPI) di Tuban, maka dapat ditampilkan pada Tabel 1 di bawah ini. 
Tabel 1. Rancangan Anggaran Belanja (RAB) Proyek Pembangunan Sarana dan Prasarana Tempat Pelelangan Ikan (TPI) Tuban

\begin{tabular}{|c|c|c|c|}
\hline \multirow[b]{2}{*}{$\begin{array}{l}\text { Minggu } \\
\text { Ke- }\end{array}$} & \multirow[b]{2}{*}{$\begin{array}{l}\text { Hari } \\
\text { Ke- }\end{array}$} & \multicolumn{2}{|c|}{ RAB (Variabel $B C W S)$} \\
\hline & & $\begin{array}{c}\text { Per minggu } \\
\text { (Rp) }\end{array}$ & Komulatif (Rp) \\
\hline 1 & 3 & $79.831 .840,20$ & $79.831 .840,20$ \\
\hline 2 & 10 & $146.294 .251,74$ & $226.126 .091,94$ \\
\hline 3 & 17 & $170.291 .895,27$ & $396.417 .987,21$ \\
\hline 4 & 24 & $261.665 .688,27$ & $658.083 .675,80$ \\
\hline 5 & 31 & $227.376 .470,16$ & $885.460 .145,64$ \\
\hline 6 & 38 & $280.325 .178,63$ & $1.165 .785 .324,30$ \\
\hline 7 & 45 & $328.512 .831,57$ & $1.494 .250 .064,40$ \\
\hline 8 & 52 & 391.079.834, & $1.885 .377 .989,90$ \\
\hline 9 & 59 & 392.282.120, & $2.277 .660 .110,70$ \\
\hline 10 & 66 & $350.971 .548,06$ & $2.628 .631 .658,70$ \\
\hline 11 & 73 & $244.352 .759,07$ & $2.872 .984 .418,80$ \\
\hline 12 & 80 & $178.948 .359,87$ & $3.051 .932 .777,70$ \\
\hline 13 & 87 & $252.768 .766,32$ & $3.304 .749 .635,50$ \\
\hline 14 & 94 & $271.764 .896,97$ & $3.571 .705 .385,40$ \\
\hline 15 & 101 & $164.472 .827,40$ & $3.736 .178 .212,80$ \\
\hline 16 & 108 & $219.729 .926,43$ & $3.955 .908 .139,30$ \\
\hline 17 & 115 & $223.144 .420,80$ & $4.179 .100 .651,50$ \\
\hline 18 & 122 & $217.373 .444,40$ & $4.396 .474 .095,90$ \\
\hline 19 & 129 & $213.285 .669,45$ & $4.609 .711 .673,90$ \\
\hline 20 & 136 & $97.192 .860,87$ & $4.706 .904 .534,80$ \\
\hline 21 & 143 & $63.721 .197,75$ & $4.770 .625 .732,50$ \\
\hline 22 & 150 & $26.450 .308,50$ & 4.797.076.041,00 \\
\hline
\end{tabular}

Sumber: Data diolah (2020)

Pada Tabel 1, diperlihatkan rancangan anggaran belanja proyek terjadwal dalam 150 hari kalender dimulai dari 12 Juli hingga batas akhir penyelesaian proyek 8 Desember tahun 2018. Pada masing-masing periode minggu tersebut, terdistribusi besarnya anggaran tiap periode per minggu dan secara komulatif nilai anggaran proyek adalah sebesar Rp. 4.797.076.041 (\#Empat milyar tujuh ratus sembilan puluh tujuh juta tujuh puluh enam ribu empat puluh satu rupiah\#). Besarnya nilai anggaran tersebut, dalam penjumlahan semua periode/komulatif (150 hari) dinamakan variabel Budgeted Cost for Work Schedule (BCWS).

Rani (2016) mengatakan bahwa manajemen dalam pelaksanaan konstruksi dilakukan dengan perencanaan dan penjadwalan, yaitu proses yang mencoba meletakkan dasar tujuan dan dasar sasaran termasuk menyiapkan segala sumber daya untuk mencapai tujuan dan sasaran tersebut. Tujuan dalam pelaksanaan konstruksi adalah untuk menyelesaikan pekerjaan dan mendapat keuntungan dari total biaya yang dikeluarkan. Adapun sasaran dalam pelaksanaan konstruksi adalah pengembangan usaha dan peningkatan produktivitas. Berkaitan dengan pelaksanaan dalam penelitian mengenai kinerja biaya proyek, maka pengeluaran aktual pada Proyek Pembangunan Sarana dan Prasarana Tempat Pelelangan Ikan (TPI) di Tuban adalah terdiri dari rekapitulasi biaya-biaya yang terdiri dari: tenaga kerja, material, administrasi \& umum, manajemen, dan lain-lainnya. Berdasarkan atas hasil rekapitulasi biaya aktual proyek pada obyek yang diteliti, dapat disajikan pada Tabel 2 berikut ini:

Tabel 2. Biaya Aktual Pembiayaan Proyek Pembangunan Sarana dan Prasarana Tempat Pelelangan Ikan (TPI) di Tuban (Variabel $A C W P$ )

\begin{tabular}{|c|c|c|c|}
\hline $\begin{array}{c}\text { Mi } \\
\text { ngg } \\
\mathbf{u} \\
\text { Ke- }\end{array}$ & $\begin{array}{c}\mathrm{Ha} \\
\text { ri } \\
\mathrm{Ke}-\end{array}$ & $\begin{array}{c}\text { Variabel } \\
\text { ACWP per } \\
\text { minggu (Rp) }\end{array}$ & $\begin{array}{c}\text { Variabel } \\
A C W P \\
\text { komulatif } \\
(\mathbf{R p})\end{array}$ \\
\hline 1 & 3 & $103.348 .569,03$ & $\begin{array}{c}103.348 .569,0 \\
3\end{array}$ \\
\hline 2 & 10 & 133.694 & $\begin{array}{c}236.994 .769,1 \\
6\end{array}$ \\
\hline 3 & 17 &, 80 & $\begin{array}{c}325.483 .068,9 \\
6\end{array}$ \\
\hline 4 & 24 & & $\begin{array}{c}580.800 .683,1 \\
9\end{array}$ \\
\hline 5 & 31 & 326. & $\begin{array}{c}907.582 .221,8 \\
4\end{array}$ \\
\hline 6 & 38 & 149. & $\begin{array}{c}1.076 .816 .104 \\
.80\end{array}$ \\
\hline 7 & 45 & $515.781 .015,75$ & $\begin{array}{c}1.592 .645 .212 \\
, 00\end{array}$ \\
\hline 8 & 52 & 307. & $\begin{array}{c}1.899 .901 .613 \\
, 80\end{array}$ \\
\hline 9 & 59 & 279. & $\begin{array}{c}2.179 .793 .969 \\
, 20\end{array}$ \\
\hline 10 & 66 & $291.503 .491,14$ & $\begin{array}{c}2.471 .324 .460 \\
, 40\end{array}$ \\
\hline 1 & 73 & $193.712 .441,16$ & $\begin{array}{c}2.665 .036 .901 \\
, 50\end{array}$ \\
\hline
\end{tabular}


Vol. 5 No.1 Januari 2022

http://jurnal.umsb.ac.id/index.php/RANGTEKNIKJOURNAL

\begin{tabular}{|c|c|c|c|}
\hline & 80 & & \\
\hline 12 & & $392.859 .218,43$ & 3.057 .896 .12 \\
\hline 13 & 87 & $349.384 .529,55$ & $\begin{array}{c}3.407 .280 .649 \\
, 50\end{array}$ \\
\hline 14 & 94 & $260.511 .492,99$ & $\begin{array}{c}3.667 .792 .142 \\
, 50\end{array}$ \\
\hline 15 & 101 & & $\begin{array}{c}3.803 .410 .087 \\
, 90\end{array}$ \\
\hline 16 & 108 & 176. & $\begin{array}{c}3.981 .156 .161 \\
.00\end{array}$ \\
\hline 17 & 115 & 179 & $\begin{array}{c}4.159 .431 .240 \\
, 30\end{array}$ \\
\hline 18 & 122 & $165.867 .480,03$ & $\begin{array}{c}4.325 .298 .720 \\
, 30\end{array}$ \\
\hline 19 & 129 & & $\begin{array}{c}4.477 .363 .948 \\
, 50\end{array}$ \\
\hline 20 & 136 & $124.412 .632,89$ & $\begin{array}{c}4.601 .776 .581 \\
, 40\end{array}$ \\
\hline 21 & 143 & $110.610 .381,00$ & $\begin{array}{c}4.712 .386 .962 \\
, 40\end{array}$ \\
\hline-1 & 150 & $96.760 .034,64$ & $\begin{array}{c}4.809 .147 .000 \\
.00\end{array}$ \\
\hline
\end{tabular}

\begin{tabular}{|r|r|r|r|}
\cline { 1 - 2 } 2 & 10 & 4,93 & 236.495 .848 \\
\hline 3 & 17 & 6,77 & 324.762 .048 \\
\hline 4 & 24 & 12,08 & 579.486 .786 \\
\hline 5 & 31 & 18,87 & 905.208 .249 \\
\hline 6 & 38 & 23,39 & 1.122 .036 .086 \\
\hline 7 & 45 & 33,18 & 1.591 .669 .830 \\
\hline 8 & 52 & 39,51 & 1.895 .324 .744 \\
\hline 9 & 59 & 45,33 & 2.174 .514 .569 \\
\hline 10 & 66 & 51,39 & 2.465 .217 .377 \\
\hline 11 & 73 & 55,42 & 2.658 .539 .542 \\
\hline 12 & 80 & 63,59 & 3.050 .460 .654 \\
\hline 13 & 87 & 70,85 & 3.398 .728 .375 \\
\hline 14 & 94 & 76,27 & 3.658 .729 .896 \\
\hline 15 & 101 & 79,09 & 3.794 .007 .441 \\
\hline 16 & 108 & 82,78 & 3.971 .019 .547 \\
\hline 17 & 115 & 86,49 & 4.148 .991 .068 \\
\hline 18 & 122 & 89,94 & 4.314 .490 .191 \\
\hline 19 & 129 & 93,10 & 4.466 .077 .794 \\
\hline 20 & 136 & 95,69 & 4.590 .322 .063 \\
\hline 21 & 143 & 97,99 & 4.700 .654 .812 \\
\hline 22 & 150 & 100,00 & 4.797 .076 .041 \\
\hline
\end{tabular}

Pada Tabel 2, diperlihatkan pengeluaran biaya aktual proyek sesuai dengan pencatatan dalam akuntansi pelaksanaan proyek, yang terdiri untuk pengeluaran periode per minggu dan dalam penjumlahan komulatif. Besarnya nilai pengeluaran biaya aktual pada obyek yang diteliti sebesar Rp. 4.809.147.000 (\#Empat milyar delapan ratus sembilan juta seratus empat puluh ribu rupiah\#), dalam konsep nilai hasil dinamakan variabel Actual Cost for Work Performed (ACWP).

Soeharto (1995) menjelaskan bahwa metode nilai hasil (earned value method) untuk mengukur kinerja proyek dengan membandingkan nilai pekerjaan yang dianggarkan dengan aktual yang diselesaikan untuk mengetahui apakah kinerja biaya masih sesuai dengan yang direncanakan. Berdasarkan atas data yang diperoleh dalam penelitian ini, maka hasil penghitungan nilai hasil (earned value) ditampilkan pada Tabel 3 di bawah ini. Tabel 3. Nilai Hasil (Earned Value) Proyek Pembangunan Sarana dan Prasarana Tempat Pelelangan Ikan (TPI) Tuban (Variabel $B C W P$ ).

\begin{tabular}{|c|c|c|c|}
\hline $\begin{array}{c}\text { Minggu } \\
\text { ke- }\end{array}$ & $\begin{array}{c}\text { Hari } \\
\text { Ke- }\end{array}$ & $\begin{array}{c}\text { Bobot } \\
\text { Penyelesaian } \\
(\%)\end{array}$ & $\begin{array}{c}\text { Variabel } \\
\boldsymbol{B C W P}(\mathbf{R p})\end{array}$ \\
\hline 1 & 3 & 2,15 & 103.137 .135 \\
\hline
\end{tabular}

Seperti yang disajikan pada Tabel 3, dapat dilihat persentase bobot penyelesaian pekerjaan (\%) dan hasil penghitungan nilai hasil yang diperoleh dalam pelaksanaan proyek yang diteliti. Nilai hasil (earned value) adalah hasil yang didapat berdasarkan pekerjaan yang telah diselesaikan dan dihitung berdasarkan persentase bobot yang didapat dikalikan dengan komulatif anggaran (nilai kontrak). Berdasarkan atas nilai hasil yang telah didapatkan dalam pelaksanaan proyek pada obyek yang diteliti diperoleh jumlah sebesar Rp. 4.797.076.041 (\#Empat milyar tujuh ratus sembilan puluh juta tujuh puluh enam ribu empat puluh satu rupiah\#), dalam konsep nilai hasil disebut variabel Budgeted Cost for Work Performed (BCWP).

Seperti yang kita ketahui bersama bahwa dalam konsep nilai hasil, menggunakan Kurva $\mathrm{S}$ yang bisa menjelaskan mengenai kondisi kemajuan proyek. Husen (2011) menyatakan bahwa evaluasi proyek untuk mengendalikan biaya adalah bentuk Kurva $S$ yang dimodifikasi menjadi 3 (tiga) variabel, yaitu:

1. Rencana dari volume dan biaya pekerjaan (BCWS). 
2. Realisasi dari volume pekerjaan dan rencana biaya $(B C W P)$.

3. Realisasi biaya dan volume pekerjaan $(A C W P)$.

Lebih lanjut, Husen (2011) menjelaskan bahwa untuk memantau kondisi keuangan proyek dalam pembiayaan proyek, perlu dibuat kurva yang dinamakan Kurva S. Pada pembuatan Kurva $S$ tampilan informasi dengan Sumbu X menunjukkan durasi proyek dan Sumbu Y menyatakan komulatif biayanya.
Anggaran komulatif biaya ditunjukkan oleh variabel biaya $B C W S, B C W P$, dan $A C W P$. Pada Kurva $S$ yang terbentuk dapat menggambarkan terjadinya pembengkakan atau penghematan kinerja proyek dari segi biaya. Berdasarkan atas data yang diperoleh dalam penelitian pada Proyek Pembangunan Sarana dan Prasarana Tempat Pelelangan Ikan (TPI) di Tuban, maka bentuk Kurva $S$ dapat dilihat pada Gambar 1 sebagai berikut ini.

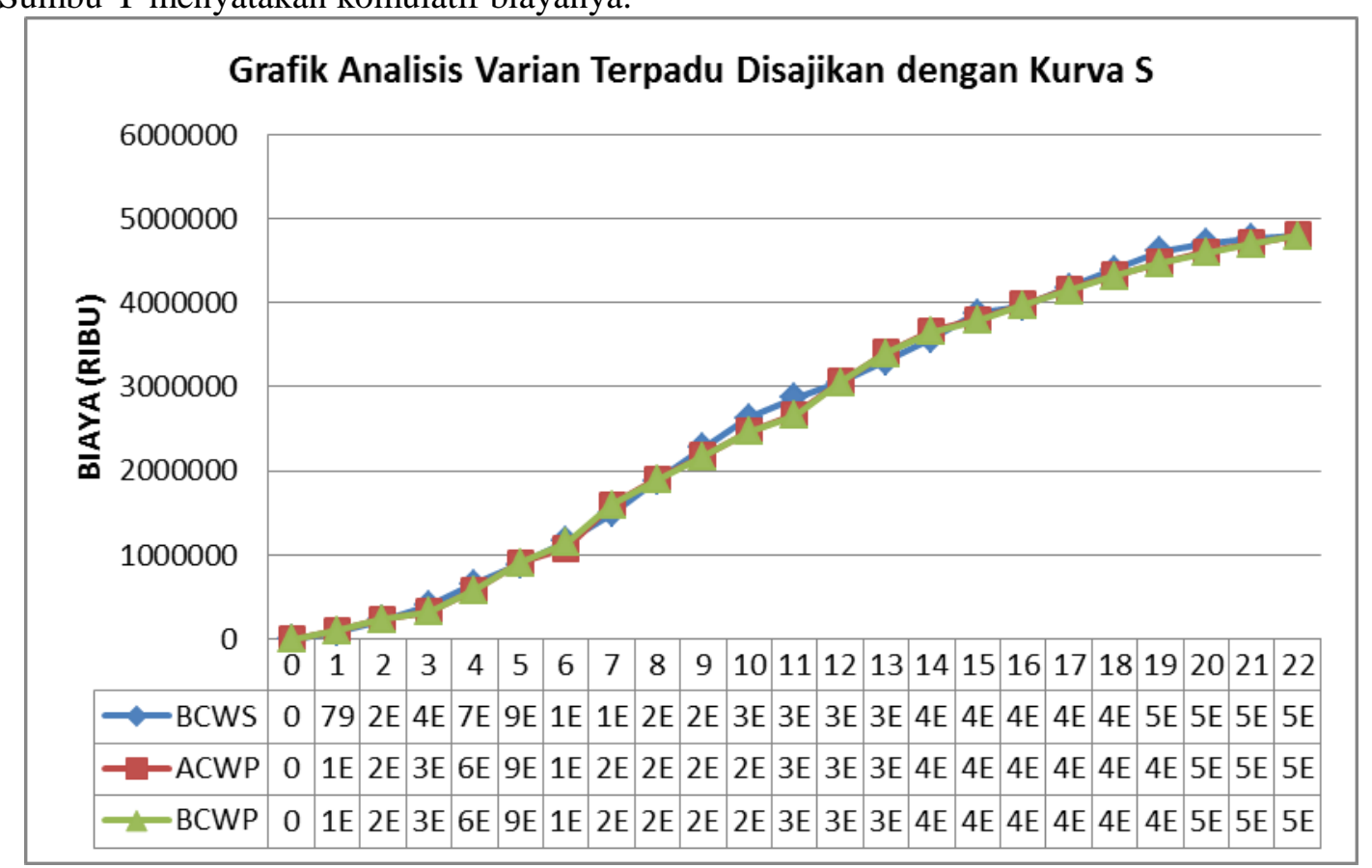

Gambar 1. Kurva S Kinerja Biaya Proyek Pembangunan Sarana dan Prasarana Tempat Pelelangan

Pada Gambar 1 di atas, maka diperlihatkan mengenai variabel $B C W S$, $A C W P$, dan $B C W P$ yang mencerminkan status kinerja biaya proyek. Pada kurva tersebut tampak bahwa biaya aktual proyek (ACWP) ditandai pada garis berwarna merah, biaya anggaran $(B C W S)$ ditandai dengan garis berwarna biru, dan nilai hasil $(B C W P)$ ditandai dengan garis berwarna hijau. Dengan pencapaian posisi ke-3 variabel yang diperlihatkan pada Kurva S yang terbentuk, maka ke-3 variabel tersebut berjalan berimpitan sehingga status kinerja biaya proyek masih belum terlihat jelas performanya. Hal tersebut dapat terjadi karena kemungkinan ke-3 variabel tersebut mempunyai nilai masing-masing yang relatif hampir sama, sehingga dalam ploting pada sumbu Y di Kurva S tidak bisa dibaca adanya perbedaan atas kurva yang terbentuk. Meskipun demikian, pada metode nilai hasil

\section{Ikan (TPI) Tuban}

(earned value) kejadian tersebut tidak masalah karena masih ada analisis lanjutan terdiri dari penghitungan indikator varian biaya (cost variance) dan indek kinerja biaya (cost performance index), adanya perbedaan sekecil apapun pasti akan dapat dideteksi atau diketahui.

Untuk bisa memperlihatkan status kinerja biaya proyek pada obyek yang diteliti, maka analisis dilanjutkan dengan penghitungan indikator varian biaya (cost variance). Indikator ini menunjukkan status proyek yang berkaitan dengan kinerja biaya proyek, yaitu dapat menyatakan seberapa besar biaya aktual melebihi biaya yang direncanakan ataupun sebaliknya. Pada penelitian Proyek Pembangunan Sarana dan Prasarana Tempat Pelelangan Ikan (TPI) di Tuban, didapatkan besaran/indikator cost variance terlihat pada Tabel 4 berikut ini. 
Tabel 4. Indikator Cost Variance (Varian Biaya) Proyek Pembangunan Sarana dan Prasarana Tempat Pelelangan Ikan (TPI) di Tuban

\begin{tabular}{|c|c|c|c|c|}
\hline $\begin{array}{l}\text { Min } \\
\text { ggu } \\
\text { ke- }\end{array}$ & $\begin{array}{c}\text { Variab } \\
\text { el } \\
B C W P \\
(\mathbf{R p}) \\
\end{array}$ & $\begin{array}{c}\text { Variab } \\
\text { el } \\
A C W P \\
(\mathbf{R p}) \\
\end{array}$ & $\begin{array}{c}\text { Indika } \\
\text { tor } C V \\
\text { (Rp) }\end{array}$ & $\begin{array}{c}\text { Perfor } \\
\text { masi } \\
\text { Biaya }\end{array}$ \\
\hline 1 & $\begin{array}{c}103.137 \\
.135\end{array}$ & $\begin{array}{c}103.348 \\
.569\end{array}$ & $\begin{array}{c}\text { ( } \\
311.14\end{array}$ & $\begin{array}{c}\text { Biaya } \\
\text { Angga } \\
\text { ran }< \\
\text { Biaya } \\
\text { Aktual }\end{array}$ \\
\hline 2 & $\begin{array}{c}236.495 \\
.848\end{array}$ & $\begin{array}{c}236.994 \\
.769\end{array}$ & $\begin{array}{c}(498.9 \\
21)\end{array}$ & $\begin{array}{c}\text { Biaya } \\
\text { Angga } \\
\text { ran }< \\
\text { Biaya } \\
\text { Aktual }\end{array}$ \\
\hline 3 & $\begin{array}{c}324.762 \\
.048 \\
\end{array}$ & $\begin{array}{c}325.483 \\
.068 \\
\end{array}$ & $\begin{array}{c}(721.0 \\
20)\end{array}$ & $\begin{array}{c}\text { Biaya } \\
\text { Angga } \\
\text { ran }< \\
\text { Biaya } \\
\text { Aktual }\end{array}$ \\
\hline 4 & $\begin{array}{c}579.486 \\
.786 \\
\end{array}$ & $\begin{array}{c}580.800 \\
.683 \\
\end{array}$ & $\begin{array}{c}(1.313 . \\
897)\end{array}$ & $\begin{array}{c}\text { Biaya } \\
\text { Angga } \\
\text { ran }< \\
\text { Biaya } \\
\text { Aktual }\end{array}$ \\
\hline 5 & $\begin{array}{c}905.208 \\
.249\end{array}$ & $\begin{array}{c}907.582 \\
.221\end{array}$ & $\begin{array}{c}(2.373 . \\
972)\end{array}$ & $\begin{array}{c}\text { Biaya } \\
\text { Angga } \\
\text { ran }< \\
\text { Biaya } \\
\text { Aktual }\end{array}$ \\
\hline 6 & $\begin{array}{l}1.122 .0 \\
36.086\end{array}$ & $\begin{array}{l}1.076 .8 \\
16.104\end{array}$ & $\begin{array}{c}45.219 . \\
982\end{array}$ & $\begin{array}{c}\text { Biaya } \\
\text { Angga } \\
\text { ran } \\
>\text { Biay } \\
\text { a } \\
\text { Aktual }\end{array}$ \\
\hline 7 & $\begin{array}{l}1.591 .6 \\
69.830\end{array}$ & $\begin{array}{l}1.592 .6 \\
45.212\end{array}$ & $\begin{array}{c}(975.3 \\
82)\end{array}$ & $\begin{array}{c}\text { Biaya } \\
\text { Angga } \\
\text { ran }< \\
\text { Biaya } \\
\text { Aktual }\end{array}$ \\
\hline 8 & $\begin{array}{l}1.895 .3 \\
24.744\end{array}$ & $\begin{array}{l}1.899 .9 \\
01.613\end{array}$ & $\begin{array}{c}(4.576 . \\
869)\end{array}$ & $\begin{array}{c}\text { Biaya } \\
\text { Angga } \\
\text { ran }< \\
\text { Biaya } \\
\text { Aktual }\end{array}$ \\
\hline & $\begin{array}{c}2.174 .5 \\
14.569\end{array}$ & $\begin{array}{l}2.179 .7 \\
93.969\end{array}$ & $\begin{array}{c}(5.279 . \\
400)\end{array}$ & $\begin{array}{c}\text { Biaya } \\
\text { Angga } \\
\text { ran }< \\
\text { Biaya } \\
\text { Aktual }\end{array}$ \\
\hline
\end{tabular}

\begin{tabular}{|c|c|c|c|c|}
\hline 10 & $\begin{array}{c}2.465 .2 \\
17.377 \\
\end{array}$ & $\begin{array}{l}2.471 .3 \\
24.460\end{array}$ & $\begin{array}{c}(6.107 . \\
083)\end{array}$ & $\begin{array}{c}\text { Biaya } \\
\text { Angga } \\
\text { ran }< \\
\text { Biaya } \\
\text { Aktual }\end{array}$ \\
\hline 11 & $\begin{array}{l}2.658 .5 \\
39.542\end{array}$ & $\begin{array}{c}2.665 .0 \\
36.901\end{array}$ & $\begin{array}{c}(6.497 . \\
359)\end{array}$ & $\begin{array}{c}\text { Biaya } \\
\text { Angga } \\
\text { ran }< \\
\text { Biaya } \\
\text { Aktual }\end{array}$ \\
\hline 12 & $\begin{array}{l}3.050 .4 \\
60.654 \\
\end{array}$ & $\begin{array}{l}3.057 .8 \\
96.120\end{array}$ & $\begin{array}{c}(7.435 . \\
466)\end{array}$ & $\begin{array}{c}\text { Biaya } \\
\text { Angga } \\
\text { ran }< \\
\text { Biaya } \\
\text { Aktual }\end{array}$ \\
\hline 13 & & $\begin{array}{l}3.407 .2 \\
80.649\end{array}$ & $\begin{array}{c}(8.552 . \\
274)\end{array}$ & $\begin{array}{c}\text { Biaya } \\
\text { Angga } \\
\text { ran } \\
<\text { Biay } \\
\text { a } \\
\text { Aktual }\end{array}$ \\
\hline 14 & & $\begin{array}{l}3.667 .7 \\
92.142\end{array}$ & $\begin{array}{c}(9.062 . \\
246)\end{array}$ & $\begin{array}{c}\text { Biaya } \\
\text { Angga } \\
\text { ran }< \\
\text { Biaya } \\
\text { Aktual }\end{array}$ \\
\hline 15 & & & $\begin{array}{c}(9.402 . \\
646)\end{array}$ & $\begin{array}{c}\text { Biaya } \\
\text { Angga } \\
\text { ran }< \\
\text { Biaya } \\
\text { Aktual }\end{array}$ \\
\hline 16 & & & & $\begin{array}{c}\text { Biaya } \\
\text { Angga } \\
\text { ran }< \\
\text { Biaya } \\
\text { Aktual }\end{array}$ \\
\hline 17 & $\begin{array}{r}4.148 .9 \\
91.068\end{array}$ & $\begin{array}{c}4.159 .4 \\
31.240\end{array}$ & $\begin{array}{l}(10.44 \\
0.172)\end{array}$ & $\begin{array}{c}\text { Biaya } \\
\text { Angga } \\
\text { ran }< \\
\text { Biaya } \\
\text { Aktual }\end{array}$ \\
\hline 18 & $\begin{array}{c}4.314 .4 \\
90.191\end{array}$ & $\begin{array}{l}4.325 .2 \\
98.720\end{array}$ & $\begin{array}{l}(10.80 \\
8.529)\end{array}$ & $\begin{array}{c}\text { Biaya } \\
\text { Angga } \\
\text { ran }< \\
\text { Biaya } \\
\text { Aktual }\end{array}$ \\
\hline 19 & $\begin{array}{r}4.466 .0 \\
77.794 \\
\end{array}$ & $\begin{array}{c}4.477 .3 \\
63.948 \\
\end{array}$ & $\begin{array}{l}(11.28 \\
6.154) \\
\end{array}$ & $\begin{array}{c}\text { Biaya } \\
\text { Angga } \\
\text { ran }< \\
\text { Biaya } \\
\text { Aktual }\end{array}$ \\
\hline & $\begin{array}{l}4.590 .3 \\
22.063\end{array}$ & $\begin{array}{l}4.601 .7 \\
76.581\end{array}$ & $\begin{array}{l}(11.45 \\
4.518)\end{array}$ & $\begin{array}{c}\text { Biaya } \\
\text { Angga } \\
\text { ran }<\end{array}$ \\
\hline
\end{tabular}




\begin{tabular}{|c|c|c|c|c|}
\hline & & & & $\begin{array}{c}\text { Biaya } \\
\text { Aktual }\end{array}$ \\
\hline 21 & $\begin{array}{c}4.700 .6 \\
54.812\end{array}$ & $\begin{array}{l}4.712 .3 \\
86.962\end{array}$ & $\begin{array}{l}(11.73 \\
2.150)\end{array}$ & $\begin{array}{c}\text { Biaya } \\
\text { Angga } \\
\text { ran }< \\
\text { Biaya } \\
\text { Aktual }\end{array}$ \\
\hline 22 & $\begin{array}{c}4.797 .0 \\
76.041\end{array}$ & $\begin{array}{l}4.809 .1 \\
47.000\end{array}$ & $\begin{array}{l}(12.07 \\
0.959)\end{array}$ & $\begin{array}{c}\text { Biaya } \\
\text { Angga } \\
\text { ran }< \\
\text { Biaya } \\
\text { Aktual }\end{array}$ \\
\hline
\end{tabular}

Sumber: Data diolah (2020)

Pada Tabel 4, berdasarkan perhitungan dari nilai variabel $B C W P$ dikurangi nilai variabel $A C W P$; maka diperoleh indikator kinerja biaya yang dinamakan cost variance (varian biaya). Pada tabel tersebut, diperlihatkan besaran $C V$ pada minggu ke-1 hingga masa berakhirnya proyek pada minggu ke-22 semuanya berjalan di angka negatif, kecuali pada minggu ke-6 menunjukkan nilai $C V$ bernilai positif sebesar Rp. 45.219.982. Dengan pencapaian nilai indikator $C V$ komulatif sebesar (Rp. 12.070.959) pada obyek proyek yang diteliti, maka pada proyek tersebut biaya aktual pembiayaan proyek melebihi dari anggaran proyek sebesar Rp. 12.079.959. Atau dapat dikatakan bahwa pada pelaksanaan proyek tersebut biaya aktual mengalami pembengkakan senilai Rp. 12.079.959. Berdasarkan Ervianto (2005) dinyatakan bahwa biaya volume aktual lebih besar dari biaya aktual/terjadi pembengkakan biaya proyek, kondisi ini dinamakan cost overrun. Demikian pula, Patiarsa (2015) menyatakan hal yang sama terkait $C V$ bernilai negatif, yaitu bahwa dalam pelaksanaan proyek terjadi biaya lebih besar dari anggaran. Dengan demikian, kinerja biaya yang dijalankan pada proyek tersebut telah menunjukkan kerja yang kurang optimal dan biaya belum bisa dikendalikan dengan baik.

Untuk lebih menunjukkan dan menambah keyakinan bahwa telah terjadi pembengkakan pada pelaksanaan proyek pada obyek yang diteliti, maka analisa perlu dilanjutkan dengan penghitungan cost performance index (CPI). Cost performance index dihitung dengan cara melakukan pembagian variabel $B C W P$ dengan variabel $A C W P$. Berdasarkan atas nilai variabel $B C W P$ dan nilai variabel $A C W P$ pada obyek yang diteliti, maka hasil penghitungan dengan menggunakan metode konsep nilai hasil didapatkan indek dari cost performance index (CPI) seperti tersaji pada Tabel 5 di bawah ini.

Tabel 5. Indek Kinerja Biaya (CPI) Proyek Pembangunan Sarana dan Prasarana Tempat Pelelangan Ikan (TPI) di Tuban

\begin{tabular}{|c|c|c|c|c|}
\hline $\begin{array}{l}\text { Min } \\
\text { ggu } \\
\text { Ke- }\end{array}$ & $\begin{array}{c}\text { Variabel } \\
A C W P \\
\text { (Rp) }\end{array}$ & $\begin{array}{c}\text { Variabel } \\
B C W P \\
(\mathbf{R p})\end{array}$ & $\begin{array}{c}\text { Ind } \\
\text { ek } \\
C P \\
I\end{array}$ & $\begin{array}{c}\text { Perfor } \\
\text { masi } \\
\text { Biaya }\end{array}$ \\
\hline 1 & $\begin{array}{c}103.348 . \\
569\end{array}$ & $\begin{array}{c}103.137 . \\
135\end{array}$ & $\begin{array}{l}0.9 \\
98 \\
\end{array}$ & $\begin{array}{c}\text { Biaya } \\
\text { Anggar } \\
\text { an }< \\
\text { Biaya } \\
\text { Aktual } \\
\end{array}$ \\
\hline 2 & $\begin{array}{c}236.994 . \\
769\end{array}$ & $\begin{array}{c}236.495 \\
848\end{array}$ & $\begin{array}{c}0,9 \\
98\end{array}$ & $\begin{array}{c}\text { Biaya } \\
\text { Anggar } \\
\text { an }< \\
\text { Biaya } \\
\text { Aktual }\end{array}$ \\
\hline 3 & $\begin{array}{c}325.483 . \\
068\end{array}$ & $\begin{array}{c}324.762 . \\
048\end{array}$ & $\begin{array}{c}0,9 \\
98\end{array}$ & $\begin{array}{c}\text { Biaya } \\
\text { Anggar } \\
\text { an }< \\
\text { Biaya } \\
\text { Aktual }\end{array}$ \\
\hline 4 & $\begin{array}{c}580.800 \\
683\end{array}$ & $\begin{array}{c}579.486 . \\
786\end{array}$ & $\begin{array}{l}0,9 \\
98\end{array}$ & $\begin{array}{c}\text { Biaya } \\
\text { Anggar } \\
\text { an }< \\
\text { Biaya } \\
\text { Aktual }\end{array}$ \\
\hline 5 & $\begin{array}{c}907.582 . \\
221\end{array}$ & $\begin{array}{c}905.208 . \\
249\end{array}$ & $\begin{array}{l}0,9 \\
98\end{array}$ & $\begin{array}{c}\text { Biaya } \\
\text { Anggar } \\
\text { an }< \\
\text { Biaya } \\
\text { Aktual }\end{array}$ \\
\hline 6 & $\begin{array}{c}1.076 .81 \\
6.104\end{array}$ & $\begin{array}{c}1.122 .03 \\
6.086\end{array}$ & $\begin{array}{l}1.0 \\
42\end{array}$ & $\begin{array}{c}\text { Biaya } \\
\text { Anggar } \\
\text { an }> \\
\text { Biaya } \\
\text { Aktual }\end{array}$ \\
\hline 7 & $\begin{array}{c}1.592 .64 \\
5.212\end{array}$ & $\begin{array}{c}1.591 .66 \\
9.830\end{array}$ & $\begin{array}{l}0,9 \\
99 \\
\end{array}$ & $\begin{array}{c}\text { Biaya } \\
\text { Anggar } \\
\text { an }< \\
\text { Biaya } \\
\text { Aktual }\end{array}$ \\
\hline 8 & $\begin{array}{c}1.899 .90 \\
1.613\end{array}$ & $\begin{array}{c}1.895 .32 \\
4.744\end{array}$ & $\begin{array}{l}0,9 \\
98\end{array}$ & $\begin{array}{c}\text { Biaya } \\
\text { Anggar } \\
\text { an }<\end{array}$ \\
\hline
\end{tabular}




\begin{tabular}{|c|c|c|c|c|}
\hline & & & & $\begin{array}{c}\text { Biaya } \\
\text { Aktual }\end{array}$ \\
\hline 9 & $\begin{array}{c}2.179 .79 \\
3.969\end{array}$ & $\begin{array}{c}2.174 .51 \\
4.569\end{array}$ & $\begin{array}{l}0,9 \\
98\end{array}$ & $\begin{array}{c}\text { Biaya } \\
\text { Anggar } \\
\text { an }< \\
\text { Biaya } \\
\text { Aktual }\end{array}$ \\
\hline 10 & $\begin{array}{c}2.471 .32 \\
4.460 \\
\end{array}$ & $\begin{array}{c}2.465 .21 \\
7.377 \\
\end{array}$ & $\begin{array}{l}0,9 \\
98 \\
\end{array}$ & $\begin{array}{c}\text { Biaya } \\
\text { Anggar } \\
\text { an }< \\
\text { Biaya } \\
\text { Aktual }\end{array}$ \\
\hline 11 & $\begin{array}{c}2.665 .03 \\
6.901 \\
\end{array}$ & $\begin{array}{c}2.658 .53 \\
9.542 \\
\end{array}$ & $\begin{array}{l}0,9 \\
98 \\
\end{array}$ & $\begin{array}{c}\text { Biaya } \\
\text { Anggar } \\
\text { an }< \\
\text { Biaya } \\
\text { Aktual } \\
\end{array}$ \\
\hline 12 & $\begin{array}{c}3.057 .89 \\
6.120\end{array}$ & $\begin{array}{c}3.050 .46 \\
0.654\end{array}$ & $\begin{array}{l}0,9 \\
98\end{array}$ & $\begin{array}{c}\text { Biaya } \\
\text { Anggar } \\
\text { an }< \\
\text { Biaya } \\
\text { Aktual }\end{array}$ \\
\hline 13 & $\begin{array}{c}3.407 .28 \\
0.649 \\
\end{array}$ & $\begin{array}{c}3.398 .72 \\
8.375 \\
\end{array}$ & $\begin{array}{l}0,9 \\
98 \\
\end{array}$ & $\begin{array}{c}\text { Biaya } \\
\text { Anggar } \\
\text { an }< \\
\text { Biaya } \\
\text { Aktual }\end{array}$ \\
\hline 14 & $\begin{array}{c}3.667 .79 \\
2.142 \\
\end{array}$ & $\begin{array}{c}3.658 .72 \\
9.896 \\
\end{array}$ & $\begin{array}{c}0,9 \\
98 \\
\end{array}$ & $\begin{array}{c}\text { Biaya } \\
\text { Anggar } \\
\text { an }< \\
\text { Biaya } \\
\text { Aktual } \\
\end{array}$ \\
\hline 15 & $\begin{array}{c}3.803 .41 \\
0.087 \\
\end{array}$ & $\begin{array}{c}3.794 .00 \\
7.441\end{array}$ & $\begin{array}{l}0,9 \\
98 \\
\end{array}$ & $\begin{array}{c}\text { Biaya } \\
\text { Anggar } \\
\text { an }< \\
\text { Biaya } \\
\text { Aktual }\end{array}$ \\
\hline 16 & $\begin{array}{c}3.981 .15 \\
6.161 \\
\end{array}$ & $\begin{array}{c}3.971 .01 \\
9.547 \\
\end{array}$ & $\begin{array}{l}0,9 \\
98 \\
\end{array}$ & $\begin{array}{c}\text { Biaya } \\
\text { Anggar } \\
\text { an }< \\
\text { Biaya } \\
\text { Aktual } \\
\end{array}$ \\
\hline 17 & $\begin{array}{c}4.159 .43 \\
1.240 \\
\end{array}$ & $\begin{array}{c}4.148 .99 \\
1.068 \\
\end{array}$ & $\begin{array}{l}0,9 \\
98 \\
\end{array}$ & $\begin{array}{c}\text { Biaya } \\
\text { Anggar } \\
\text { an }< \\
\text { Biaya } \\
\text { Aktual } \\
\end{array}$ \\
\hline 18 & $\begin{array}{c}4.325 .29 \\
8.720\end{array}$ & $\begin{array}{c}4.314 .49 \\
0.191\end{array}$ & $\begin{array}{l}0,9 \\
98\end{array}$ & $\begin{array}{c}\text { Biaya } \\
\text { Anggar } \\
\text { an }< \\
\text { Biaya } \\
\text { Aktual }\end{array}$ \\
\hline 19 & $\begin{array}{c}4.477 .36 \\
3.948\end{array}$ & $\begin{array}{c}4.466 .07 \\
7.794\end{array}$ & $\begin{array}{l}0,9 \\
97\end{array}$ & $\begin{array}{c}\text { Biaya } \\
\text { Anggar }\end{array}$ \\
\hline
\end{tabular}

\begin{tabular}{|c|c|c|c|c|}
\hline & & & & $\begin{array}{c}\text { an } \\
\text { Biaya } \\
\text { Aktual }\end{array}$ \\
\hline 20 & $\begin{array}{c}4.601 .77 \\
6.581 \\
\end{array}$ & $\begin{array}{c}4.590 .32 \\
2.063\end{array}$ & $\begin{array}{l}0,9 \\
98 \\
\end{array}$ & $\begin{array}{c}\text { Biaya } \\
\text { Anggar } \\
\text { an }< \\
\text { Biaya } \\
\text { Aktual }\end{array}$ \\
\hline 21 & $\begin{array}{c}4.712 .38 \\
6.962 \\
\end{array}$ & $\begin{array}{c}4.700 .65 \\
4.812 \\
\end{array}$ & $\begin{array}{l}0,9 \\
97\end{array}$ & $\begin{array}{c}\text { Biaya } \\
\text { Anggar } \\
\text { an }< \\
\text { Biaya } \\
\text { Aktual } \\
\end{array}$ \\
\hline 22 & $\begin{array}{l}4.809 .14 \\
7.000\end{array}$ & $\begin{array}{c}4.797 .07 \\
6.041\end{array}$ & $\begin{array}{l}0,9 \\
98 \\
\end{array}$ & $\begin{array}{c}\text { Biaya } \\
\text { Anggar } \\
\text { an }< \\
\text { Biaya } \\
\text { Aktual }\end{array}$ \\
\hline
\end{tabular}

Sumber: Data diolah (2020)

Seperti ditampakkan pada Tabel 5, maka diperlihatkan bahwa indek kinerja biaya (cost performance index) pada minggu ke-1 hingga berakhirnya proyek pada minggu ke-22 pada proyek yang menjadi obyek penelitian diperoleh angka kurang dari 1, kecuali pada minggu ke-6 diperoleh indek di atas 1 (1.042). Dengan pencapain indek kinerja biaya tersebut dan secara komulatif didapatkan indek CPI sebesar 0.998, telah memberikan petunjuk yang jelas dan meyakinkan bahwa memang benar telah terjadi pembengkakan biaya pada pelaksanaan obyek yang menjadi obyek penelitian. Hal ini sesuai yang dikemukakan oleh Pastiarsa (2015) bahwa dengan pencapaian cost performance index $(C P I)<1$ artinya proyek berjalan dengan biaya lebih boros dari anggaran.

Meskipun demikian, terjadinya pembengkakan biaya aktual proyek terhadap anggaran pada proyek yang menjadi obyek penelitian dengan pencapaian indek kinerja biaya 0.998 dan nilainya sebesar Rp. 12.070.959 menunjukkan bahwa penyimpangannya relatif kecil. Dengan anggaran sesuai pada rancangan anggaran belanja proyek pada Proyek Pembangunan Sarana dan Prasarana Tempat Pelelangan Ikan (TPI) di Tuban, maka pembengkakan dapat dihitung sebagai berikut ini:

Pembengkakan biaya (\%) $=($ Rp. 12.070.959/Rp. 4.797.076.041) $\mathrm{x}$ 
Dengan perolehan kinerja biaya yang telah menunjukkan pemborosan anggaran sebesar $2.5 \%$, maka cukup memberikan masukan bagi pelaksana proyek untuk melakukan pembenahan dalam pengendalian biaya pada proyek supaya terjadinya pemborosan anggaran bisa dicegah.

\section{Evalusai Kinerja Jadwal Proyek}

Husen (2011) menjelaskan bahwa hal yang berlaku umum saat ini dalam monitor dan evaluasi proyek dalam mengendalikan waktu adalah dengan menggunakan Kurva S, yaitu plotting dan komulatif persentase bobot pekerjaan dari nilai biaya, yang dapat mempresentasikan kemajuan dari awal hingga akhir proyek. Kurva $\mathrm{S}$ sebagai alat monitor dan evaluasi yang informatif, menampilkan kombinasi menggunakan diagram batang, sehingga pengelola proyek dapat cepat mengantisipasi bila ada penyimpangan pada proyek.
Lebih lanjut, Husen (2011) menjelaskan bahwa untuk memantau kondisi jadwal proyek dalam pelaksanaan proyek, perlu dibuat kurva yang dinamakan Kurva S. Pada pembuatan Kurva $\mathrm{S}$ tampilan informasi dengan menggunakan Sumbu $X$ yang menunjukkan durasi proyek dan Sumbu Y menyatakan komulatif biayanya. Anggaran komulatif biaya ditunjukkan oleh variabelvariabel biaya yang terdiri dari $B C W S, B C W P$, dan $A C W P$. Pada Kurva $S$ yang terbentuk tersebut dapat menggambarkan terjadinya percepatan, kelambatan atau tepat jadwal kinerja proyek dari segi jadwal pelaksanaan proyek.

Berdasarkan data yang diperoleh dalam pelaksanaan penelitian pada Proyek Pembangunan Sarana dan Prasarana Tempat Pelelangan Ikan (TPI) di Tuban, maka status kinerja waktu dapat dilihat pada Gambar 2 berikut ini.

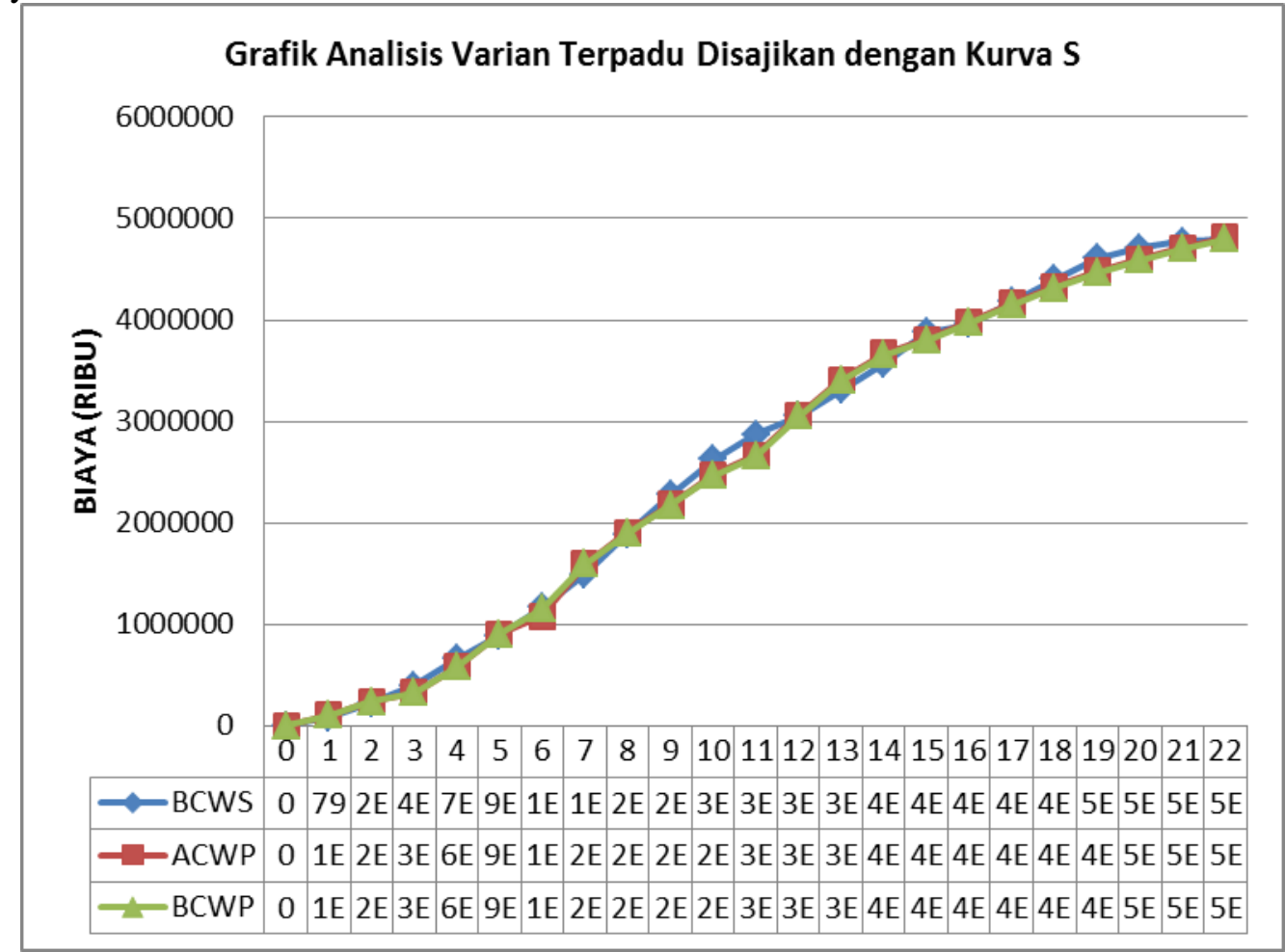

Gambar 2. Indikator Kinerja Waktu dengan Kurva S pada Proyek Pembangunan Sarana dan Prasarana Tempat Pelelangan Ikan (TPI) di Tuban

Pada Gambar 2, dapat dilihat kinerja waktu pada obyek penelitian ditampilkan dalam grafik yang disajikan dalam Kurva S. Diharapkan dari kurva tersebut dapat menggambarkan terjadinya keterlambatan atau percepatan kinerja proyek dari segi jadwal pelaksanaan proyek. Pada kurva tersebut diperlihatkan bahwa realisasi waktu pengerjaan proyek pada Sumbu X berjalan dari minggu ke-1 hingga minggu ke-22 dan progres kemajuan proyek ditunjukkan pada Sumbu Y. Pada kurva tersebut tampak bahwa biaya aktual proyek $(A C W P)$ ditandai pada garis berwarna merah, biaya anggaran (BCWS) ditandai dengan garis berwarna biru, dan nilai 
hasil $(B C W P)$ ditandai dengan garis berwarna hijau. Dengan pencapaian posisi ke-3 variabel yang diperlihatkan pada Kurva $S$ yang terbentuk, maka ke-3 variabel tersebut berjalan berimpitan sehingga status kinerja jadwal proyek masih belum terlihat jelas apakah terjadi kelambatan atau percepatan dalam pelaksanaan proyek tersebut. Hal tersebut dapat terjadi karena kemungkinan ke-3 variabel tersebut mempunyai nilai masingmasing yang relatif hampir sama, sehingga dalam ploting pada sumbu $\mathrm{Y}$ di Kurva S tidak bisa dibaca adanya perbedaan atas kurva yang terbentuk. Meskipun demikian, pada metode nilai hasil (earned value) kejadian tersebut tidak masalah karena masih ada analisis lanjutan terdiri dari penghitungan indikator varian jadwal (schedule variance) dan indek kinerja jadwal (schedule performance index), adanya perbedaan sekecil apapun pasti akan dapat dideteksi atau diketahui.

Untuk bisa memperlihatkan status kinerja jadwal proyek pada obyek yang diteliti, maka analisis dilanjutkan dengan penghitungan indikator varian jadwal (schedule variance). Indikator ini dapat menunjukkan status proyek yang berkaitan dengan kinerja waktu proyek, berdasarkan atas perolehan nilai dari penghitungan indikator tersebut dalam pelaksanaan sebuah proyek. Indikator schedule variance (SV) mempunyai peluang nilai terdiri angka negatif, angka positif, atau angka 0. Dengan perolehan nilai yang didapatkan pada penghitungan indikator schedule variance tersebut, akan dapat menjelaskan status proyek berkaitan dengan kinerja jadwal proyek, apakah terjadi percepatan, kelambatan atau tepat jadwal pelaksanaan proyek. Indikator schedule variance dihitung dari pengurangan variabel $B C W S$ terhadap BCWP. Pada penelitian Proyek Pembangunan Sarana dan Prasarana Tempat Pelelangan Ikan (TPI) di Tuban, didapatkan besaran/indikator schedule variance $(S V)$ terlihat pada Tabel 6 sebagai berikut ini.

Tabel 6. Indikator Schedule Variance (Varian Jadwal) Proyek Pembangunan Sarana dan Prasarana Tempat Pelelangan Ikan (TPI) di Tuban

\begin{tabular}{|c|c|c|c|}
\hline $\begin{array}{l}\text { Ming } \\
\text { gu } \\
\text { Ke- }\end{array}$ & $\begin{array}{l}\text { Variabel } \\
\text { BCWP } \\
(\mathrm{Rp})\end{array}$ & $\begin{array}{l}\text { Variabel } \\
\text { BCWS } \\
\text { (Rp) }\end{array}$ & $\begin{array}{l}\text { Indikator } \\
S V(\mathrm{Rp})\end{array}$ \\
\hline 1 & $\begin{array}{c}103.137 .1 \\
35 \\
\end{array}$ & $\begin{array}{c}79.831 .84 \\
0 \\
\end{array}$ & $\begin{array}{c}23.305 .29 \\
5 \\
\end{array}$ \\
\hline 2 & $\begin{array}{c}236.495 .8 \\
48\end{array}$ & $\begin{array}{c}226.126 .0 \\
91\end{array}$ & $\begin{array}{c}10.369 .75 \\
7\end{array}$ \\
\hline 3 & $\begin{array}{c}324.762 .0 \\
48 \\
\end{array}$ & $\begin{array}{c}396.417 .9 \\
87 \\
\end{array}$ & $\begin{array}{c}(71.655 .9 \\
39) \\
\end{array}$ \\
\hline 4 & $\begin{array}{c}579.486 .7 \\
86 \\
\end{array}$ & $\begin{array}{c}658.083 .6 \\
75 \\
\end{array}$ & $\begin{array}{c}(78.596 .8 \\
89) \\
\end{array}$ \\
\hline 5 & $\begin{array}{c}905.208 .2 \\
49 \\
\end{array}$ & $\begin{array}{c}885.460 .1 \\
45 \\
\end{array}$ & $\begin{array}{c}19.748 .10 \\
4 \\
\end{array}$ \\
\hline 6 & $\begin{array}{c}1.122 .036 . \\
086\end{array}$ & $\begin{array}{c}1.165 .785 \\
324\end{array}$ & $\begin{array}{c}(43.749 .2 \\
38)\end{array}$ \\
\hline 7 & $\begin{array}{c}1.591 .669 . \\
830\end{array}$ & $\begin{array}{c}1.494 .250 . \\
064\end{array}$ & $\begin{array}{c}97.419 .76 \\
6 \\
\end{array}$ \\
\hline 8 & $\begin{array}{c}1.895 .324 . \\
744\end{array}$ & $\begin{array}{l}1.885 .377 . \\
989\end{array}$ & 9.946 .755 \\
\hline 9 & $\begin{array}{c}2.174 .514 \\
569 \\
\end{array}$ & $\begin{array}{c}2.277 .660 \\
110 \\
\end{array}$ & $\begin{array}{c}(103.145 . \\
541)\end{array}$ \\
\hline 10 & $\begin{array}{c}2.465 .217 \\
377\end{array}$ & $\begin{array}{c}2.628 .631 \\
658\end{array}$ & $\begin{array}{c}(163.414 . \\
281)\end{array}$ \\
\hline 11 & $\begin{array}{c}2.658 .539 \\
542\end{array}$ & $\begin{array}{c}2.872 .984 \\
418\end{array}$ & $\begin{array}{c}(214.444 . \\
876)\end{array}$ \\
\hline 12 & $\begin{array}{c}3.050 .460 . \\
654\end{array}$ & $\begin{array}{c}3.051 .932 . \\
777\end{array}$ & $\begin{array}{c}(1.472 .12 \\
3)\end{array}$ \\
\hline 13 & $\begin{array}{c}3.398 .728 \\
375\end{array}$ & $\begin{array}{c}3.304 .749 \\
635\end{array}$ & $\begin{array}{c}93.978 .74 \\
0\end{array}$ \\
\hline 14 & $\begin{array}{c}3.658 .729 . \\
896 \\
\end{array}$ & $\begin{array}{c}3.571 .705 . \\
385\end{array}$ & $\begin{array}{c}87.024 .51 \\
1 \\
\end{array}$ \\
\hline 15 & $\begin{array}{c}3.794 .007 . \\
441\end{array}$ & $\begin{array}{c}3.736 .178 \\
212\end{array}$ & $\begin{array}{c}57.829 .22 \\
9\end{array}$ \\
\hline 16 & $\begin{array}{c}3.971 .019 . \\
547\end{array}$ & $\begin{array}{c}3.955 .908 \\
139\end{array}$ & $\begin{array}{c}(15.111 .4 \\
08)\end{array}$ \\
\hline 17 & $\begin{array}{c}4.148 .991 . \\
068\end{array}$ & $\begin{array}{c}4.179 .100 . \\
651\end{array}$ & (30.109.5 \\
\hline
\end{tabular}


Vol. 5 No.1 Januari 2022

http://jurnal.umsb.ac.id/index.php/RANGTEKNIKJOURNAL

\begin{tabular}{|c|c|c|c|}
\hline & & & $83)$ \\
\hline & 4.314 .490$. & 4.396 .474$. & $(81.983 .9$ \\
18 & 191 & 095 & $04)$ \\
\hline & 4.466 .077$. & 4.609 .711$. & $(143.633$. \\
19 & 794 & 673 & $879)$ \\
\hline & 4.590 .322$. & 4.706 .904$. & $(116.582$. \\
20 & 063 & 534 & $471)$ \\
\hline & & & \\
& 4.700 .654$. & 4.770 .625$. & $(69.970 .9$ \\
21 & 812 & 732 & $20)$ \\
\hline & .4 .797 .076 & 4.797 .076$. & \\
22 & .041 & 041 & 0 \\
\hline
\end{tabular}

Sumber: Data diolah (2020)

Pada Tabel 6 , berdasarkan variabel $B C W S$ dan variabel $B C W P$ yang diperoleh dalam penelitian ini, maka diperlihatkan status proyek yang berkaitan dengan kinerja jadwal proyek diperoleh $S V$ bernilai positif, negarif, dan angka 0 . Pada penelitian ini didapatkan nilai-nilai dari indikator $S V$ yang cukup bervariasi, ada yang bernilai positif, nilai negatif dan angka 0. Dengan perolehan nilainilai indikator $S V$ pada proyek yang cukup bervariasi tersebut pada obyek penelitian, maka dapat dijelaskan sebagai berikut:

1. Perolehan indikator $S V$ bernilai negatif dicapai pada pelaksanaan proyek pada minggu ke-3, ke-4, ke-6, ke-9, ke-10, ke-11, ke-12, ke-17, ke-18, ke-19, ke-20, dan ke-21; mengindikasikan bahwa pada periode minggu-minggu tersebut jadwal proyek berjalan lebih lambat dari jadwal yang direncanakan. Kondisi ini dinamakan schedule overrun.

2. Perolehan indikator $S V$ bernilai positif dicapai pada pelaksanaan proyek pada minggu ke-1, ke-2, ke-5, ke-7, ke-8, ke-13, ke-14, ke-15, dan ke-16; mengindikasikan bahwa pada periode minggu-minggu tersebut jadwal proyek berjalan lebih cepat dari jadwal yang direncanakan. Kondisi ini dinamakan schedule underrun.

3. Perolehan indikator $S V$ bernilai 0 dicapai pada pelaksanaan proyek minggu ke-22, mengindikasikan bahwa pelaksanaan proyek berlangsung tepat jadwal sesuai dengan jadwal yang direncanakan. Dengan pencapaian atas nilai indikator ini, maka realisasi pelaksanaan Proyek Pembangunan Sarana dan Prasarana Tempat Pelelangan Ikan (TPI) di Tuban selesai dengan jadwal yang telah direncanakan. Kondisi ini dinamakan on schedule.

Untuk menambah keyakinan dan sekaligus melengkapi dalam analisis dengan menggunakan metode nilai hasil (eaned value), maka analisis dapat dilanjutkan untuk mendapatkan indek yang dinamakan schedule performance index (indek kinerja jadwal). Schedule performance index (SPI) dapat diperoleh dengan perhitungan pembagian dari variabel nilai hasil $(B C W P)$ dengan variabel anggaran proyek $(B C W S)$. Berdasarkan atas pelaksanaan proyek pada Proyek Pembangunan Sarana dan Prasarana Tempat Pelelangan Ikan (TPI) di Tuban didapatkan hasil perhitungan indek dari schedule performance index (SPI) disajikan pada Tabel 7 dibawah ini.

Tabel 7. Indek Kinerja Jadwal (indikator SPI) Proyek Pembangunan Sarana dan Prasarana Tempat Pelelangan Ikan (TPI) di Tuban

\begin{tabular}{|c|c|c|c|c|}
\hline $\begin{array}{l}\text { Min } \\
\text { ggu } \\
\text { Ke- }\end{array}$ & $\begin{array}{c}\text { Variabel } \\
B C W P \\
(\mathrm{Rp}) \\
\end{array}$ & $\begin{array}{c}\text { Variabel } \\
B C W S \\
(\mathrm{Rp}) \\
\end{array}$ & $\begin{array}{l}\text { Ind } \\
\text { ek } \\
\text { SPI }\end{array}$ & $\begin{array}{c}\text { Perfor } \\
\text { masi } \\
\text { Jadwal }\end{array}$ \\
\hline 1 & $\begin{array}{c}103.137 . \\
135\end{array}$ & $\begin{array}{c}79.831 .8 \\
40\end{array}$ & $\begin{array}{l}1.2 \\
92\end{array}$ & $\begin{array}{c}\text { Aktual } \\
\text { lebih } \\
\text { cepat } \\
\text { dari } \\
\text { rencana }\end{array}$ \\
\hline 2 & $\begin{array}{c}236.495 \\
848\end{array}$ & $\begin{array}{c}226.126 . \\
091\end{array}$ & $\begin{array}{l}1.0 \\
46\end{array}$ & $\begin{array}{c}\text { Aktual } \\
\text { lebih } \\
\text { cepat } \\
\text { dari } \\
\text { rencana }\end{array}$ \\
\hline 3 & $\begin{array}{c}324.762 . \\
048\end{array}$ & $\begin{array}{c}396.417 . \\
987\end{array}$ & $\begin{array}{l}0.8 \\
19 \\
\end{array}$ & $\begin{array}{c}\text { Aktual } \\
\text { lebih } \\
\text { lambat } \\
\text { dari } \\
\text { rencana }\end{array}$ \\
\hline 4 & $\begin{array}{c}579.486 \\
786\end{array}$ & $\begin{array}{c}658.083 . \\
675\end{array}$ & $\begin{array}{c}0.8 \\
81\end{array}$ & $\begin{array}{c}\text { Aktual } \\
\text { lebih } \\
\text { lambat } \\
\text { dari } \\
\text { rencana }\end{array}$ \\
\hline 5 & $\begin{array}{c}905.208 . \\
249 \\
\end{array}$ & $\begin{array}{c}885.460 . \\
145 \\
\end{array}$ & $\begin{array}{l}1.0 \\
22 \\
\end{array}$ & $\begin{array}{c}\text { Aktual } \\
\text { lebih } \\
\text { cepat } \\
\text { dari } \\
\text { rencana }\end{array}$ \\
\hline 6 & $\begin{array}{c}1.122 .03 \\
6.086\end{array}$ & $\begin{array}{c}1.165 .78 \\
5.324 \\
\end{array}$ & $\begin{array}{l}0.9 \\
62\end{array}$ & $\begin{array}{c}\text { Aktual } \\
\text { lebih } \\
\text { lambat }\end{array}$ \\
\hline
\end{tabular}




\begin{tabular}{|c|c|c|c|c|}
\hline & & & & $\begin{array}{c}\text { dari } \\
\text { rencana }\end{array}$ \\
\hline 7 & $\begin{array}{c}1.591 .66 \\
9.830\end{array}$ & $\begin{array}{c}1.494 .25 \\
0.064\end{array}$ & $\begin{array}{l}1.0 \\
65\end{array}$ & $\begin{array}{c}\text { Aktual } \\
\text { lebih } \\
\text { cepat } \\
\text { dari } \\
\text { rencana }\end{array}$ \\
\hline 8 & $\begin{array}{c}1.895 .32 \\
4.744 \\
\end{array}$ & $\begin{array}{c}1.885 .37 \\
7.989 \\
\end{array}$ & $\begin{array}{l}1.0 \\
05\end{array}$ & $\begin{array}{c}\text { Aktual } \\
\text { lebih } \\
\text { cepat } \\
\text { dari } \\
\text { rencana }\end{array}$ \\
\hline 9 & $\begin{array}{c}2.174 .51 \\
4.569\end{array}$ & $\begin{array}{c}2.277 .66 \\
0.110\end{array}$ & $\begin{array}{l}0.9 \\
55\end{array}$ & $\begin{array}{l}\text { Aktual } \\
\text { lebih } \\
\text { lambat } \\
\text { dari } \\
\text { rencana }\end{array}$ \\
\hline 10 & $\begin{array}{c}2.465 .21 \\
7.377 \\
\end{array}$ & $\begin{array}{c}2.628 .63 \\
1.658 \\
\end{array}$ & $\begin{array}{l}0.9 \\
38 \\
\end{array}$ & $\begin{array}{c}\text { Aktual } \\
\text { lebih } \\
\text { lambat } \\
\text { dari } \\
\text { rencana }\end{array}$ \\
\hline 11 & $\begin{array}{c}2.658 .53 \\
9.542 \\
\end{array}$ & $\begin{array}{c}2.872 .98 \\
4.418 \\
\end{array}$ & $\begin{array}{l}0.9 \\
25\end{array}$ & $\begin{array}{c}\text { Aktual } \\
\text { lebih } \\
\text { lambat } \\
\text { dari } \\
\text { rencana } \\
\end{array}$ \\
\hline 12 & $\begin{array}{c}3.050 .46 \\
0.654 \\
\end{array}$ & $\begin{array}{c}3.051 .93 \\
2.777 \\
\end{array}$ & $\begin{array}{l}0.9 \\
99 \\
\end{array}$ & $\begin{array}{c}\text { Aktual } \\
\text { lebih } \\
\text { lambat } \\
\text { dari } \\
\text { rencana } \\
\end{array}$ \\
\hline 13 & $\begin{array}{c}3.398 .72 \\
8.375 \\
\end{array}$ & $\begin{array}{c}3.304 .74 \\
9.635 \\
\end{array}$ & $\begin{array}{l}1.0 \\
28 \\
\end{array}$ & $\begin{array}{c}\text { Aktual } \\
\text { lebih } \\
\text { cepat } \\
\text { dari } \\
\text { rencana }\end{array}$ \\
\hline 14 & $\begin{array}{c}3.658 .72 \\
9.896\end{array}$ & $\begin{array}{c}3.571 .70 \\
5.385\end{array}$ & $\begin{array}{l}1.0 \\
24\end{array}$ & $\begin{array}{c}\text { Aktual } \\
\text { lebih } \\
\text { cepat } \\
\text { dari } \\
\text { rencana }\end{array}$ \\
\hline 15 & $\begin{array}{c}3.794 .00 \\
7.441\end{array}$ & $\begin{array}{c}3.376 .17 \\
8.212\end{array}$ & $\begin{array}{l}1.1 \\
24\end{array}$ & $\begin{array}{c}\text { Aktual } \\
\text { lebih } \\
\text { cepat } \\
\text { dari } \\
\text { rencana }\end{array}$ \\
\hline 16 & $\begin{array}{c}3.971 .01 \\
9.547\end{array}$ & $\begin{array}{c}3.955 .90 \\
8.139\end{array}$ & $\begin{array}{l}1.0 \\
04\end{array}$ & $\begin{array}{c}\text { Aktual } \\
\text { lebih } \\
\text { cepat } \\
\text { dari } \\
\text { rencana }\end{array}$ \\
\hline 17 & $\begin{array}{c}4.148 .99 \\
1.068\end{array}$ & $\begin{array}{c}4.179 .10 \\
0.651\end{array}$ & $\begin{array}{l}0.9 \\
93\end{array}$ & $\begin{array}{c}\text { Aktual } \\
\text { lebih }\end{array}$ \\
\hline
\end{tabular}

\begin{tabular}{|c|c|c|c|c|}
\hline & & & & $\begin{array}{c}\text { lambat } \\
\text { dari } \\
\text { rencana }\end{array}$ \\
\hline 18 & $\begin{array}{c}4.314 .49 \\
0.191\end{array}$ & $\begin{array}{c}4.396 .47 \\
4.095\end{array}$ & $\begin{array}{l}0.9 \\
81\end{array}$ & $\begin{array}{c}\text { Aktual } \\
\text { lebih } \\
\text { lambat } \\
\text { dari } \\
\text { rencana }\end{array}$ \\
\hline 19 & $\begin{array}{c}4.466 .07 \\
7.794\end{array}$ & $\begin{array}{c}4.609 .71 \\
1.673\end{array}$ & $\begin{array}{r}0.9 \\
69 \\
\end{array}$ & $\begin{array}{l}\text { Aktual } \\
\text { lebih } \\
\text { lambat } \\
\text { dari } \\
\text { rencana }\end{array}$ \\
\hline 20 & $\begin{array}{c}4.590 .32 \\
2.063\end{array}$ & $\begin{array}{c}4.706 .90 \\
4.534\end{array}$ & $\begin{array}{l}0.9 \\
75\end{array}$ & $\begin{array}{l}\text { Aktual } \\
\text { lebih } \\
\text { lambat } \\
\text { dari } \\
\text { rencana }\end{array}$ \\
\hline 21 & $\begin{array}{c}4.700 .65 \\
4.812\end{array}$ & $\begin{array}{c}4.770 .62 \\
5.732\end{array}$ & $\begin{array}{r}0.9 \\
85\end{array}$ & $\begin{array}{c}\text { Aktual } \\
\text { lebih } \\
\text { lambat } \\
\text { dari } \\
\text { rencana }\end{array}$ \\
\hline 22 & $\begin{array}{c}4.797 .07 \\
6.041\end{array}$ & $\begin{array}{c}4.797 .07 \\
6.041\end{array}$ & $\begin{array}{l}1.0 \\
00\end{array}$ & $\begin{array}{c}\text { Tepat } \\
\text { jadwal } \\
\text { (on } \\
\text { schedul } \\
\text { e) }\end{array}$ \\
\hline
\end{tabular}

Sumber: Data diolah (2020)

Pada Tabel 7, berdasarkan variabel $B C W S$ dan variabel $B C W P$ yang diperoleh dalam penelitian ini, maka diperlihatkan status proyek yang berkaitan dengan indek kinerja jadwal proyek diperoleh SPI bernilai kurang dari angka 1 , lebih dari angka 1 , dan angka 0. Dengan perolehan nilai-nilai indek SPI pada Proyek Pembangunan Sarana dan Prasarana Tempat Pelelangan Ikan (TPI) di Tuban, maka dapat dijelaskan sebagai berikut:

1. Perolehan indek SPI bernilai kurang dari angka 1 dicapai pada pelaksanaan proyek pada minggu ke-3, ke-4, ke-6, ke-9, ke-10, ke-11, ke-12, ke-17, ke-18, ke-19, ke-20, dan ke-21; mengindikasikan bahwa pada periode minggu-minggu tersebut jadwal proyek berjalan lebih lambat dari jadwal yang direncanakan.

2. Perolehan indek SPI bernilai lebih dari angka 1 dicapai pada pelaksanaan proyek pada minggu ke-1, ke-2, ke-5, ke-7, ke-8, ke-13, ke-14, ke-15, dan ke-16; mengindikasikan bahwa pada periode minggu-minggu tersebut jadwal proyek 
berjalan lebih cepat dari jadwal yang direncanakan.

3. Perolehan indek SPI bernilai 1 dicapai pada pelaksanaan proyek minggu ke-22, mengindikasikan bahwa pelaksanaan proyek berlangsung tepat jadwal sesuai dengan waktu yang direncanakan.

Dengan perolehan nilai indek SPI yang didapatkan pada proyek yang menjadi obyek penelitian, maka memberikan keyakinan bahwa kinerja jadwal berjalan dengan jadwal yang bervariasi, ada beberapa minggu yang mengalami keterlambatan dan adapula beberapa minggu yang mengalami percepatan. Namun begitu pada masa mendekati batas akhir jadwal proyek didapatkan indek SPI bernilai angka 0, hal ini mengindikasikan bahwa dalam pelaksanaan proyek dapat dicapai tepat jadwal sesuai dengan yang direncanakan. Dengan terjadinya penyelesaian proyek sesuai dengan rencana jadwal yang telah ditentukan, dapat dikatakan bahwa status proyek berkenaan dengan kinerja jadwal sudah baik dilakukan oleh pelaksana proyek.

\section{Evaluasi Penerapan Standar Mutu Pada Pelaksanaan Proyek}

Evaluasi penerapan standar mutu pada pelaksanaan proyek dengan cara membandingkan antara perencanaan pekerjaan (work planning) dengan kontrol mutu terhadap aplikasi aktual dalam proyek, terdiri dari volume \& satuan pekerjaan, dimensi, jenis bahan, standar mutu material, kebutuhan skill tenaga kerja, dan lain sebagainya.

Berdasarkan AACE (2011) dinyatakan tentang mutu hasil konstruksi adalah dipenuhinya persyaratan dari pihak kontraktor terhadap ketentuan-ketentuan sebagai berikut:

1. Ketentuan perencanaan kontrak, spesifikasi dan dokumen-dokumen lain yang telah dipersiapkan secara mendetail oleh kontraktor sebagai harga proposal pelelangan.

2. Penerjemahan persyaratan/tuntutan kontrak yang wajar dan memungkinkan dalam segi waktu dari staff design lapangan dan staff pengawas lapangan.

3. Kontrak untuk melakukan pekerjaan dalam jadwal yang wajar dan dapat menghasilkan keuntungan yang layak.

Husen (2011) berpendapat bahwa audit mutu adalah pengujian secara sistematis dan mandiri untuk mengetahui apakah kegiatan mutu dan hasilnya sesuai dengan aturan yang direncanakan serta diterapkan secara efektif untuk mencapai suatu tujuan. Sasarannya adalah menentukan adanya kesesuaian atau ketidaksesuaian, menilai tingkat efektivitas penerapan persyaratan, menemukan peluang perbaikan serta memenuhi persyaratan umum. Audit mutu dibedakan atas:

1. Audit Mutu Internal

Perusahaan kontraktor membuat

Manajemen Representatif (MR) yang bertanggung jawab untuk melakukan audit sistem mutu secara periodik untuk membuktikan bahwa persyaratan standar mutu berdasarkan ISO : 9002 dilaksanakan secara penuh.

2. Audit Mutu Eksternal

Audit mutu eksternal dilakukan oleh lembaga sertifikasi yang mempunyai tugas mengaudit sistem mutu ISO : 9002, yang dipilih oleh perusahaan kontraktor.

Demikian pula, Soeharto (1995) menyatakan bahwa produk atau hasil kegiatan proyek harus memenuhi spesifikasi dan kriteria yang dipersyaratkan. Berdasarkan atas rencana kerja dan syarat-syarat pekerjaan (RKS) pada Proyek Pembangunan Sarana dan Prasarana Tempat Pelelangan Ikan (TPI) di Tuban, maka memenuhi tugas yang dimaksudkan dianggap memenuhi persyaratan mutu. Oleh karena itu, untuk memudahkan penilaian terhadap pencapaian mutu pada proyek yang menjadi obyek penelitian dirancang spesifikasi teknis pekerjaan yang terdiri dari:

1. Perencanaan pekerjaan (work planning), terdiri dari uraian pekerjaan dan gambar kerja (desain).

2. Standar bahan/material yang dipersyaratkan untuk digunakan.

3. Kebutuhan keterampilan ( kill) tenaga kerja dalam pengerjaan proyek.

Dengan demikian, penilaian fisik konstruksi untuk dapat memenuhi persyaratan spesifikasi teknis pekerjaan adalah berdasarkan sebagai berikut:

1. Kesesuain pelaksanaan pekerjaan aktual dalam proyek dengan perencanaan pekerjaan (work planning).

2. Pemakaian dan penggunaan bahan/material yang digunakan berdasarkan standar bahan/material yang dipersyaratkan. 
3. Pemakaian tenaga kerja dalam pengerjaan proyek sesuai dengan kebutuhan keterampilan (skill) yang dipersyaratkan.

Oleh karena itu, maka penilaian fisik konstruksi terhadap spesifikasi teknis yang dipersyaratkan dilakukan pada semua jenis pekerjaan yang terdiri dari:

1. Pekerjaan persiapan lantai I, II, dan III.

2. Pekerjaan tanah lantai I.

3. Pekerjaan pondasi lantai I.

4. Pekerjaan beton lantai I, II, dan III.

5. Pekerjaan besi dan alumunium lantai I, II, dan III.

6. Pekerjaan pasang dinding lantai I, II, dan III.

7. Pekerjaan penutup lantai dan penutup dinding lantai I, II, dan III.

8. Pekerjaan langit-langit (plafound) lantai I,

II, dan III.

9. Pekerjaan plesteran pada lantai II dan III.

10. Pekerjaan kayu pada lantai I, II, dan III.

11. Pekerjaan kunci dan kaca pada lantai I, II, dan III.

12. Pekerjaan pengecatan pada lantai I, II, dan III.

13. Pekerjaan atap pada lantai III.

14. Pekerjaan sanitasi dalam gedung pada lantai I, II, dan III.

15. Pekerjaan elektrikal pada lantai I, II, dan III.

16. Pekerjaan sarana penunjang pada lantai I, II, dan III.

Hasil penilain fisik konstruksi terhadap spesifikasi teknis yang dipersyaratkan pada Proyek Pembangunan Sarana dan Prasarana Tempat Pelelangan Ikan (TPI) di Tuban, dapat dilihat pada Lampiran 5 sampai dengan Lampiran 20 pada bagian akhir skripsi ini. Secara ringkas hasil penilain tersebut disajikan pada Tabel 8 di bawah berikut ini.

Tabel 8. Penilaian Fisik Konstruksi terhadap Spesifikasi Teknis yang Dipersyaratkan

\begin{tabular}{|c|l|c|}
\hline No. & $\begin{array}{c}\text { Jenis } \\
\text { Pekerjaan }\end{array}$ & $\begin{array}{c}\text { Penilaian Fisik } \\
\text { Konstruksi } \\
\text { terhadap } \\
\text { Spesifikasi Teknis } \\
\text { yang } \\
\text { Dipersyaratkan }\end{array}$ \\
\hline 1 & $\begin{array}{l}\text { Pekerjaan } \\
\text { persiapan lantai } \\
\text { I, II, dan III }\end{array}$ & $\begin{array}{c}\text { Persyaratan } \\
\text { terpenuhi }\end{array}$ \\
\hline 2 & Pekerjaan tanah & Persyaratan \\
\hline
\end{tabular}

\begin{tabular}{|c|c|c|}
\hline & lantai I & terpenuhi \\
\hline 3 & $\begin{array}{l}\text { Pekerjaan } \\
\text { pondasi lantai I }\end{array}$ & $\begin{array}{c}\text { Persyaratan } \\
\text { terpenuhi }\end{array}$ \\
\hline 4 & $\begin{array}{l}\text { Pekerjaan beton } \\
\text { lantai I, II, dan } \\
\text { III }\end{array}$ & $\begin{array}{c}\text { Persyaratan } \\
\text { terpenuhi }\end{array}$ \\
\hline 5 & $\begin{array}{l}\text { Pekerjaan besi } \\
\text { dan alumunium } \\
\text { lantai I, II, dan } \\
\text { III }\end{array}$ & $\begin{array}{c}\text { Persyaratan } \\
\text { terpenuhi }\end{array}$ \\
\hline 6 & $\begin{array}{l}\text { Pekerjaan } \\
\text { pasang dinding } \\
\text { lantai I, II, dan } \\
\text { III }\end{array}$ & $\begin{array}{c}\text { Persyaratan } \\
\text { terpenuhi }\end{array}$ \\
\hline 7 & $\begin{array}{l}\text { Pekerjaan } \\
\text { penutup lantai } \\
\text { dan penutup } \\
\text { dinding lantai I, } \\
\text { II, dan III }\end{array}$ & $\begin{array}{c}\text { Persyaratan } \\
\text { terpenuhi }\end{array}$ \\
\hline 8 & $\begin{array}{l}\text { Pekerjaan } \\
\text { langit-langit } \\
\text { (plafound) lantai } \\
\text { I, II, dan III }\end{array}$ & $\begin{array}{c}\text { Persyaratan } \\
\text { terpenuhi }\end{array}$ \\
\hline 9 & $\begin{array}{l}\text { Pekerjaan } \\
\text { plesteran pada } \\
\text { lantai II dan III }\end{array}$ & $\begin{array}{c}\text { Persyaratan } \\
\text { terpenuhi }\end{array}$ \\
\hline 10 & $\begin{array}{l}\text { Pekerjaan kayu } \\
\text { pada lantai I, II, } \\
\text { dan III }\end{array}$ & $\begin{array}{c}\text { Persyaratan } \\
\text { terpenuhi }\end{array}$ \\
\hline 11 & $\begin{array}{l}\text { Pekerjaan kunci } \\
\text { dan kaca pada } \\
\text { lantai I, II, dan } \\
\text { III }\end{array}$ & $\begin{array}{c}\text { Persyaratan } \\
\text { terpenuhi }\end{array}$ \\
\hline 12 & $\begin{array}{l}\text { Pekerjaan } \\
\text { pengecatan pada } \\
\text { lantai I, II, dan } \\
\text { III }\end{array}$ & $\begin{array}{c}\text { Persyaratan } \\
\text { terpenuhi }\end{array}$ \\
\hline 13 & $\begin{array}{l}\text { Pekerjaan atap } \\
\text { pada lantai III }\end{array}$ & $\begin{array}{c}\text { Persyaratan } \\
\text { terpenuhi }\end{array}$ \\
\hline 14 & $\begin{array}{l}\text { Pekerjaan } \\
\text { sanitasi dalam } \\
\text { gedung pada } \\
\text { lantai I, II, dan } \\
\text { III }\end{array}$ & $\begin{array}{c}\text { Persyaratan } \\
\text { terpenuhi }\end{array}$ \\
\hline 15 & $\begin{array}{l}\text { Pekerjaan } \\
\text { elektrikal pada } \\
\text { lantai I, II, dan } \\
\text { III }\end{array}$ & $\begin{array}{c}\text { Persyaratan } \\
\text { terpenuhi }\end{array}$ \\
\hline 16 & $\begin{array}{l}\text { Pekerjaan sarana } \\
\text { penunjang pada } \\
\text { lantai I, II, dan } \\
\text { III }\end{array}$ & $\begin{array}{c}\text { Persyaratan } \\
\text { terpenuhi }\end{array}$ \\
\hline
\end{tabular}

Sumber: PT. Srikandi Dua Putri (2020) 
Pada Tabel 8 tersebut diperlihatkan bahwa dari ke-16 jenis pekerjaan, berdasarkan atas penilain fisik konstruksi terhadap spesifikasi teknis yang dipersyaratkan adalah memenuhi persyaratan yang dimaksudkan (persyaratan terpenuhi). Hal ini juga telah dibuktikan pada penyerahan hasil proyek (serah terima) kepada pihak pemilik proyek
Dinas Perikanan dan Peternakan Kabupaten Tuban sesuai dengan jadwal waktu yang telah ditentukan. Dengan demikian, pada pengerjaan proyek tersebut dapat dikatakan telah memenuhi mutu sesuai dengan dokumen kontrak dan syarat-syarat penggunaan.

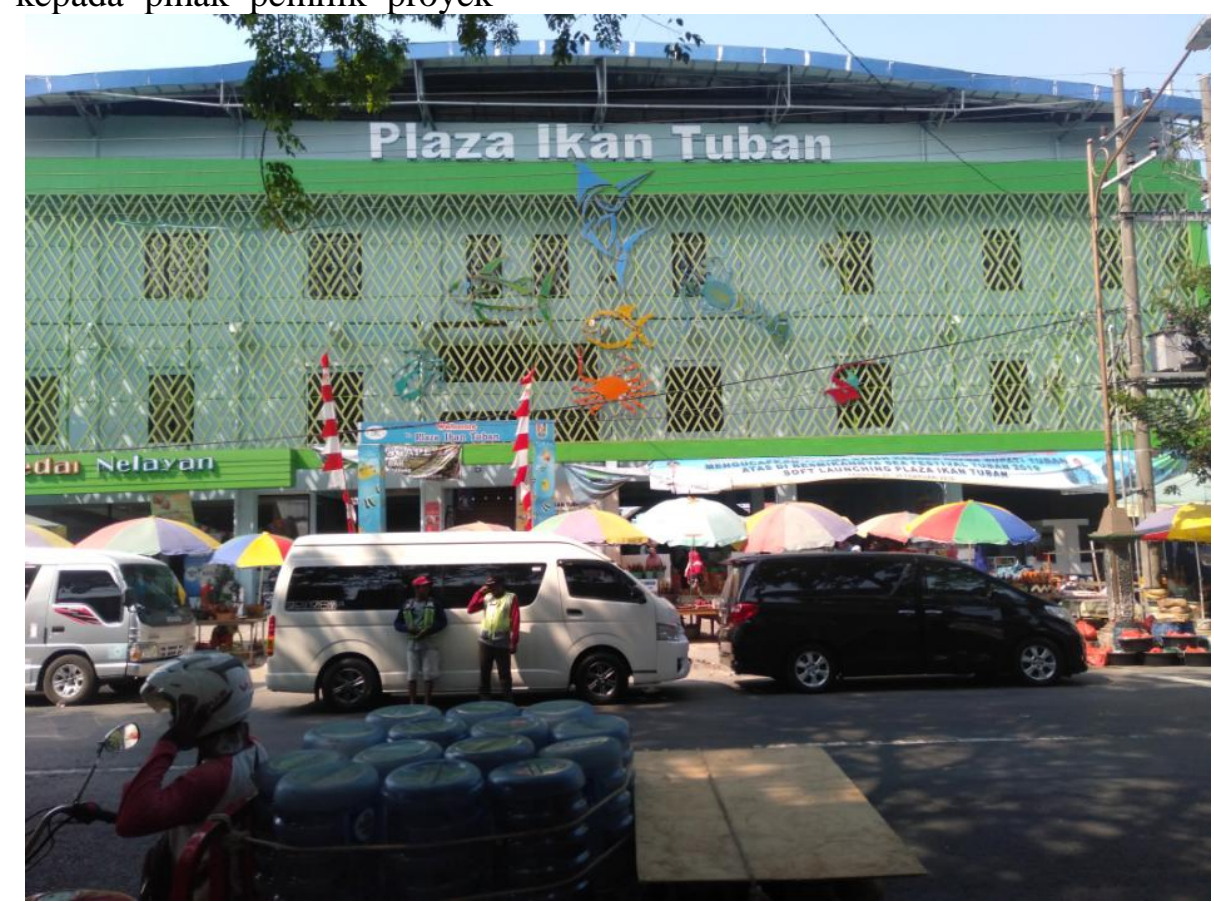

Gambar 3. Dokumentasi Penggunaan oleh Masyarakat terhadap Hasil Proyek Pembangunan Sarana dan Prasarana Tempat Pelelangan Ikan (TPI) di Tuban.

Pada Gambar 3 tersebut, dapat dilihat profil Tempat Pelelangan Ikan (TPI) di Tuban yang merupakan hasil pembangunan proyek yang telah dilakukan menjadi obyek penelitian ini. Melihat letaknya yang sangat strategis di lokasi pusat kota, tempat obyek tersebut menjelma menjadi kawasan perekonomian baru yang menggerakkan sendi-sendi ekonomi khususnya di Kota Tuban. Posisinya yang letaknya di kawasan Jalan Sudirman Tuban, sangat ramai dikunjungi bagi para pengunjung baik dari dalam kota maupun dari luar kota. Disamping lokasinya yang sangat mudah dijangkau, maka pada obyek tersebut juga dilengkapi dengan stand penjualan bagi pelaku UKM (usaha kecil menengah) untuk produkproduk olahan ikan yang bercirikan khas produksi dari Tuban.

\section{PENUTUP}

Berdasarkan atas hasil pelaksanaan penelitian pada Proyek Pembangunan Sarana dan Prasarana Tempat Pelelangan Ikan (TPI) di Tuban, maka dapat disimpulkan berapa hal sebagai berikut ini:

1. Proyek Pembangunan Sarana dan Prasarana Tempat Pelelangan Ikan (TPI) di Tuban bertujuan untuk memberikan tempat yang lebih representatif/layak bagi para nelayan untuk melakukan aktifitas jual beli ikan hasil tangkapan serta meningkatkan kenyamanan dan pelayanan bagi pembeli ikan di Kota Tuban. Disamping itu, pembangunan proyek tersebut dimaksudkan untuk lebih mengkonsentrasikan dan meningkatkan pelayanan bagi para pelaku UKM (usaha kecil menengah) melakukan aktifas penjualan berbagai produk hasil olahan ikan ciri khas dari Tuban.

2. Pada penelitian ini, evaluasi sistem manajemen pada proyek yang menjadi obyek penelitian terdiri dari evaluasi kinerja biaya proyek, evaluasi kinerja jadwal proyek, dan evaluasi penerapan mutu pada pelaksanaan proyek. Untuk evaluasi kinerja biaya dan jadwal proyek 
menggunakan metode konsep nilai hasil (earned value) dan evaluasi penerapan mutu pada pelaksanaan proyek berdasarkan penilaian fisik konstruksi terhadap spesifikasi teknis yang dipersyaratkan.

3. Berdasarkan atas evaluasi kinerja biaya proyek, maka pada proyek yang menjadi obyek penelitian dapat diketahuiterjadi pembengkakan biaya aktual proyek terhadap anggaran sebesar Rp. 12.070.959 atau pemborosan biaya sebesar $2.5 \%$ dari total anggaran biaya proyek. Kondisi ini dinamakan cost overrun (boros biaya).

4. Berdasarkan atas evaluasi kinerja jadwal proyek, maka pada proyek yang menjadi obyek penelitian berjalan dengan jadwal yang bervariasi, ada beberapa minggu yang mengalami keterlambatan dan adapula beberapa minggu yang mengalami percepatan. Namun begitu pada masa mendekati batas akhir jadwal proyek, pelaksanaan proyek dapat dicapai tepat jadwal sesuai dengan yang direncanakan. Kondisi ini dinamakan on schedule (tepat jadwal).

5. Adapun untukevaluasi penerapan mutu pada pelaksanaan proyek yang menjadi obyek penelitian, didapatkan bahwaberdasarkan atas penilain fisik konstruksi terhadap spesifikasi teknis yang dipersyaratkan memenuhi persyaratan mutu (persyaratan mutu terpenuhi dan acceptable).

\section{DAFTAR PUSTAKA}

AACE International. 2011. Development of Factored Cost Estimates: As Applied in Engineering, Procurement and Construction For the Proccess Industries. McGraw-Hill Inc., New York USA.

Asnudin. 2004.

Barry, Donald S, dan Paulson.1998. Manajemen Proyek Profesional. Erlangga, Jakarta.

Cristiawan. 2004.

Ervianto, Wulfram I. 2004. Teori-Aplikasi Manajemen Proyek Konstruksi. Andi Offset, Yogjakarta.

Fleming, O.W. dan Koppelman, J.M. 1994.The Esence and Evolution of Earned Value. AACE, Transactions.

Gray, C., Simanjuntak, P., Lien K.S., Mspaitella, P.F.L., dan Varley,
R.C.G.2007. Pengantar Evaluasi Proyek. Gramedia PustakaUtama, Jakarta.

Handoko, T.H. 1999. Manajemen Personalia dan Sumber Daya Manusia. BPFE, Yogyakarta.

Hughes, Bob dan Mike Cotterell. 2002. Software Project Management. Edisi Ke-3. McGraw-Hill, London.

Husen, Abrar. 2011. Manajemen Proyek. Andi Offset, Yogjakarta.

Kerzner. 1982. Project Management: A System Approach do Planning. Schedulling, And Controlling. Van Nostrand Reinhold, New York.

Prasetya dan Fitri. 2009.

Purnomo. 2007.

Rani, Hanifdar A. 2016. Manajemen Proyek Konstruksi. Deepublish, Yogjakarta.

Schwalbe, Kathy. 2004. Information Technology Project Management. Edisi Ke-4.Course Technology, Inc.Boston.

Smith, D. J. 1995.Reability Maintainability. Buterworth, Heinmann.

Soeharto, Iman. 1995. Manajemen Proyek: Dari Konseptual Sampai Operasional. Penerbit Erlangga, Jakarta.

Soeharto, Iman. 1997. ManajemenProyekdariKonseptualSamp aiOperasional. Edisi 2. Cetakan 1. Penerbit Erlangga, Jakarta.

Soeharto, Iman. 1999.ManajemenKonstruksidariKonsept ualHinggaOperasional. Penerbit Erlangga, Jakarta.

Soemardi, B.W. 2006. Pengembangan Sistem Earned Value untuk Pengelolaan Proyek Konstruksi di Indonesia. Laporan Hasil Riset, ITB Bandung.

Sumarniningsih. 2002.

Wibowo. 2006.

Widiasanti, Irika dan Lenggogeni. 2014. Manajemen Konstruksi. PT. Remaja Rosdakarya, Bandung.

Yahya,I.G.D. 2013.Studi Pengendalian Biaya dan Jadwal Proyek dengan Menggunakan Nilai Hasil.Skripsi tidak publikasi.Universitas Hasanuddin, Makassar. 